Article

\title{
Migration Intentions of Romanian Engineering Students
}

\author{
Vasile Gherhes ${ }^{1, *(\mathbb{D})}$, Gabriel-Mugurel Dragomir ${ }^{2}$ and Mariana Cernicova-Buca ${ }^{1, *(1)}$ \\ 1 Department of Communication and Foreign Languages, Politehnica University Timișoara, \\ 300006 Timișoara, Romania \\ 2 Department of Teaching Training, Politehnica University Timișoara, 300006 Timișoara, Romania; \\ mugur.dragomir@upt.ro \\ * Correspondence: vasile.gherhes@upt.ro (V.G.); mariana.cernicova@upt.ro (M.C.-B.)
}

Received: 13 May 2020; Accepted: 11 June 2020; Published: 13 June 2020

check for updates

\begin{abstract}
This paper aims to diagnose Romanian engineering students in relation to their migration intentions, motivations, and destinations, and to predict the magnitude of migration in the polled population. It presents the results of a quantitative study based on a questionnaire survey consistent in terms of number and structure of variables and responses. The online questionnaire was self-administered by 1782 students from the five major technical Romanian universities, which are the main providers of the highly skilled labor force in the area of engineering. Regression analysis was carried out to correlate the drivers of migration and the potential for real migration. According to the results, Romanian students from technical universities are inclined to migrate in a significant proportion; the economic factor being the main migration driver. The predictive model built on the logistical regression and the collected data accounts only partially for the variations of the variable decision to migrate, so further research is needed. The analysis of the students' mindset can prove useful to understand the future interactions between the new graduates and the labor market, to develop regional and national policies regarding human capital, and to root development plans towards sustainable economic growth in solid databases concerning the engineering profession.
\end{abstract}

Keywords: migration; higher education; engineering students; brain drain; destination country

\section{Introduction}

In the academic tradition, mobility is part of the university culture, encouraged and practiced for centuries. The assumption is that a highly skilled, educated person needs to be exposed to a variety of experiences and contexts in order to put his/her abilities to the best use and reach the maximum potential. However, when mobility shifts towards migration flows, the phenomenon is of increased importance for the country of origin. The trend is significant enough to be analyzed, not only on scientific and educational, but also on political levels. Brain drain favors countries with strong economic standing, clear development paths, and well-established reputations for integrating immigrating human capital.

Previous studies on migration intentions open a variety of research paths, such as reasons to migrate [1-6], directions and (i) reversibility of migration flows [1-3,7-14], perceived incentives and barriers for migration $[1,7,8,15-18]$, policies in place for encouraging migration of skilled workers vs. cohesion policies to prevent the European Union from encountering a deepening of East-West economic disparities $[19,20]$, actual experiences of expat highly skilled workers in the destination country with respect to a variety of realities [13,20-22], or identity-building and perceptions of highly skilled workers-on-the move [5,20,23]. Visvizi, Pachocka, and Lytras group the existing literature on migration under three main questions: “(i) Why people leave or take the decision to move; (ii) Why 
the receiving countries decide to welcome (or not) migrants; (iii) How to ensure that both the sending countries and the receiving countries are able to safeguard their own sustainability" [24] (p. 272).

Our own literature review shows that, while migration and its migration waves, forces, causes, and effects have stirred the interest of many researchers from a variety of disciplines over the years, recent reports and studies refine the features pertaining to youth migration in the 21st century. We systematized the wealth of knowledge according to the topic, the geographic focus, the migrant population taken into consideration, and the research focus and method (see Appendix A).

Our research targets the motives animating students and recent graduates to migrate. In the literature dealing with this topic, there is a balance between comparative approaches (focusing on several countries or large geographic regions) and in-depth country analyses. The preferred analytical method is the survey, and the data are either collected by the researchers or drawn from official statistics, as presented in the table below.

The table highlights the multifaceted issue of migration drivers and scientific paradigms used to unveil young people's decision-making processes concerning their personal and professional future. The phenomenon is of utmost importance even when only intra-European migration is analyzed, because the push-pull factors used by developed countries to encourage high-skilled workers to immigrate or the measures undertaken by developing countries to reverse the migration flows and retain the needed workforce at home can be influenced through a better and in-depth understanding of the issues considered by the young generation.

In a recent report on migration and brain drain, the World Bank [7] points to the fact that, in the emerging and developing countries of Europe and Central Asia, the emigration rates of high-skilled workers are high. On a closer look, in Eastern Europe and the Balkans, the regime change at the end of the 20th century and the entry of many of these countries into the European Union opened the doors of Western Europe to many young professionals As a result, "emigration from Romania increased 287 percent between 1990 and 2017. High-skilled workers in Romania experienced the highest emigration rate, with 27 percent of the total stock of such workers living abroad in 2017" [7] (p. 65). According to the World Bank [7] (p. 65), this "led to labor supply shortages, especially in science and technology fields".

In the last decade, more than a fourth (26\%) of the Romanians living in Romania expressed a desire to permanently settle abroad if they had the opportunity, the percentage rising in the young population. According to the Organization for Economic Co-operation and Development (OECD), in a study commissioned by the Romanian Foreign Ministry, Romania ranked fifth in the total emigrant population, with the highest emigration rate among the ten main origin countries of emigrants living in OECD countries. Nearly half of the young people in the age group 15-24-years in Romania said they intended to emigrate, the percentage being most likely related to poor job prospects for people at the early stage of their career, especially for higher-education graduates [8]. The popular press, policy studies such as the one on the movement of skilled labor published by the European Union [9], and research articles on the issue [10,15] particularly emphasize the migration of health care professionals from Romania [16,17]. Less attention, if any, is devoted to analyzing data regarding the engineering profession, although there is a general assumption that "engineering skills and knowledge are foundational to technological innovation and development that drive long-term economic growth and help solve societal challenges" and are vital for ensuring and maintaining the competitiveness of a country [25]. In recent years, only one article specifically discusses the engineering students' migration, though from an Asian perspective [26], the others covering either students as a generation (rarely distinguishing between specializations) or focusing on medical students (see Appendix A). Below (Table 1) we present a synoptic view of the motivations, animating students to consider migration as a post-graduate important option for them. 
Table 1. Samples and variables analyzed in discussing students' migration intentions.

\begin{tabular}{|c|c|c|c|}
\hline Author/Country & $\begin{array}{c}\text { Sample/Population } \\
\text { Number of } \\
\text { Respondents }\end{array}$ & $\begin{array}{l}\text { Analyzed Migration } \\
\text { Intention/Question }\end{array}$ & Analytical Method \\
\hline $\begin{array}{l}\text { Hemming et al. } \\
\text { [27]/European countries } \\
\text { (survey in Germany, } \\
\text { Hungary, Luxembourg, } \\
\text { Norway, Romania, } \\
\text { Spain) }\end{array}$ & $\begin{array}{l}\text { Youth/Online survey: N } \\
=5499 \\
\text { Qualitative interview: N } \\
=152\end{array}$ & $\begin{array}{l}\text { Influence of the } \\
\text { country-type } \\
\text { characteristics on the } \\
\text { macro-level } \\
\text { corresponding with } \\
\text { individual motivations } \\
\text { for intra-European youth } \\
\text { mobility }\end{array}$ & $\begin{array}{l}\text { Multi-methods } \\
\text { design: Macro } \\
\text { analysis on the } \\
\text { national level with } \\
\text { individual } \\
\text { qualitative and } \\
\text { quantitative } \\
\text { analysis of mobile } \\
\text { youth (micro-data } \\
\text { from online } \\
\text { survey+ } \\
\text { interviews). }\end{array}$ \\
\hline $\begin{array}{l}\text { Dohlman et al. } \\
\text { [15]/Global }\end{array}$ & $\begin{array}{l}\text { Physicians and medical } \\
\text { students/19 articles } \\
\text { excerpted from PubMed, } \\
\text { Web of Science, EBSCO } \\
\text { MEDLINE, Google } \\
\text { Scholar databases }\end{array}$ & $\begin{array}{l}\text { Codification of } \\
\text { questionnaires asking for } \\
\text { motives to emigrate } \\
\text { according to Maslow's } \\
\text { theory: basic food and } \\
\text { shelter needs, physical } \\
\text { and financial security, a } \\
\text { need for social belonging, } \\
\text { desire to improve } \\
\text { educational or } \\
\text { professional } \\
\text { opportunities } \\
\text { (self-esteem), and } \\
\text { self-actualization }\end{array}$ & $\begin{array}{l}\text { Literature review, } \\
\text { data mining }\end{array}$ \\
\hline $\begin{array}{l}\text { Sandu and Tufis, } 2018 \\
{[1] / \text { New and Old }} \\
\text { member states of the EU }\end{array}$ & $\begin{array}{l}\text { Youth/ } \mathrm{N}=12,708, \\
\text { weighted data }\end{array}$ & $\begin{array}{l}\text { Intentions, motivations, } \\
\text { intensity, self-assessment } \\
\text { of migration motivations } \\
\text { and behavior; } 17 \text { reasons } \\
\text { for the first migration } \\
\text { reduced to five latent } \\
\text { dimensions: job, } \\
\text { personal communities, } \\
\text { education, lifestyle, } \\
\text { personal problems }\end{array}$ & $\begin{array}{l}\text { Multi-country } \\
\text { comparative } \\
\text { analysis, data from } \\
\text { YMOBILITY } \\
\text { survey }\end{array}$ \\
\hline $\begin{array}{l}\text { Ciarniene and } \\
\text { Kumpikaite, } 2011 \\
\text { [28]/Lithuania }\end{array}$ & Students/N $=220$ & $\begin{array}{l}\text { Reasons for migration: } \\
\text { economic, political, } \\
\text { socio-demographic, } \\
\text { cultural, demographical }\end{array}$ & $\begin{array}{l}\text { Logical analysis, } \\
\text { survey }\end{array}$ \\
\hline $\begin{array}{l}\text { Plopeanu et al., } 2018 \\
\text { [3]/Romania }\end{array}$ & $\begin{array}{l}\text { Students in economics, } \\
\text { three universities (Iasi, } \\
\text { Cluj-Napoca, Sibiu)/N = } \\
3051\end{array}$ & $\begin{array}{l}\text { Variables influencing the } \\
\text { likelihood to migrate } \\
\text { after graduation: } \\
\text { personal fulfilment } \\
\text { through migration } \\
\text { (personal value } \\
\text { recognition), degree of } \\
\text { individual freedom, level } \\
\text { of religiosity, previous } \\
\text { educational performance, } \\
\text { parental role models, and } \\
\text { migration experiences } \\
\text { abroad }\end{array}$ & $\begin{array}{l}\text { Survey, descriptive } \\
\text { statistics }\end{array}$ \\
\hline $\begin{array}{l}\text { Wazir et al., } 2017 \\
\text { [26]/Malaysia }\end{array}$ & $\begin{array}{l}\text { Engineering students, } \\
\text { public and private } \\
\text { universities/N = } 227\end{array}$ & $\begin{array}{l}\text { Pull factors: employment } \\
\text { opportunities, career } \\
\text { advancement, salary, } \\
\text { employment benefits, } \\
\text { and safer and lower } \\
\text { crime rate in destination } \\
\text { countries }\end{array}$ & Survey \\
\hline
\end{tabular}


Table 1. Cont

\begin{tabular}{|c|c|c|c|}
\hline Author/Country & $\begin{array}{c}\text { Sample/Population } \\
\text { Number of } \\
\text { Respondents }\end{array}$ & $\begin{array}{l}\text { Analyzed Migration } \\
\text { Intention/Question }\end{array}$ & Analytical Method \\
\hline Iacob, 2018 [5]/Romania & $\begin{array}{l}\text { Highly skilled } \\
\text { workers/N = } 370\end{array}$ & $\begin{array}{l}\text { Potential brain drain } \\
\text { reasons: economic } \\
\text { factors (economic } \\
\text { instability, unsatisfying } \\
\text { salary level in Romania, } \\
\text { impossibility to find a } \\
\text { work position to } \\
\text { correspond to the } \\
\text { professional skills in } \\
\text { Romania, infrastructure); } \\
\text { socio-political factors } \\
\text { (political instability, } \\
\text { legislative instability, } \\
\text { corruption, status of the } \\
\text { education system, status } \\
\text { of the sanitary system, } \\
\text { reunification with family } \\
\text { already established } \\
\text { abroad, social pressure, } \\
\text { Romanian life style), and } \\
\text { organizational factors } \\
\text { (limited number of } \\
\text { carrier opportunities, } \\
\text { leadership at the work } \\
\text { place in Romania, the } \\
\text { interaction with } \\
\text { co-workers in Romania). }\end{array}$ & Survey \\
\hline $\begin{array}{l}\text { Suciu et al., } 2017 \\
\text { [16]/Romania }\end{array}$ & $\begin{array}{l}\text { Medical student } \\
\text { graduates of a Romanian } \\
\text { university/N = } 957\end{array}$ & $\begin{array}{l}\text { Pull factors: higher wage } \\
\text { abroad, better living and } \\
\text { working condition } \\
\text { abroad, disappointment } \\
\text { with the Romania } \\
\text { healthcare system, } \\
\text { gaining living and } \\
\text { working experience } \\
\text { abroad, personal reason } \\
\text { (my partner wants to } \\
\text { work/is working abroad), } \\
\text { more professional } \\
\text { opportunities, shortage } \\
\text { of residency } \\
\text { opportunities in the } \\
\text { chosen specialty in } \\
\text { Romania, and lack of job } \\
\text { vacancies in the chosen } \\
\text { specialty in Romania }\end{array}$ & Survey \\
\hline $\begin{array}{l}\text { Herz et al., } 2019 \\
\text { [29]/Europe }\end{array}$ & Youth/N = 5499 & $\begin{array}{l}\text { Influence of (1) } \\
\text { macro-structures, (2) } \\
\text { individual, (3) } \\
\text { family/household, and } \\
\text { (4) social networks on } \\
\text { migration intentions }\end{array}$ & $\begin{array}{l}\text { Descriptive analysis, } \\
\text { multiple logistic } \\
\text { regression analysis, prior } \\
\text { data (survey) }\end{array}$ \\
\hline $\begin{array}{l}\text { Van Mol, } 2016 \text { [30]/EU } \\
\text { (28 states) }\end{array}$ & Youth/N = 13,437 & $\begin{array}{l}\text { Analysis of individual } \\
\text { and contextual factors } \\
\text { related to migration } \\
\text { aspirations (mainly } \\
\text { economic) }\end{array}$ & $\begin{array}{l}\text { Survey, descriptive } \\
\text { analysis }\end{array}$ \\
\hline
\end{tabular}


In Romania, the proportion of graduates in the so-called science, technology, engineering and mathematics (STEM) group is higher than the European Union average, yet evidence shows that from a different perspective, due to low participation in higher education, there are 14.4 graduates in STEM for every 1000 people aged 20-29 compared to an EU average of 19.1, as shown in the EU Education and Training Monitor. Skills shortage on the labor market is increased due to the diminishing numbers of new graduates in science and engineering and to emigration [31] (p. 7). The knowledge-based economy, a target for the countries in the European Union zone, depends on four pillars, out of which human capital is a vital component. For its development and progress, a country relies, not only on an economic and institutional regime that fosters the use of existing knowledge, the creation of new knowledge, and entrepreneurship, but also on a dynamic infrastructure capable of disseminating information relating to both an educated population capable of creating and using knowledge and universities and other organizations that are skilled in accessing global knowledge and adapting it to local needs while also acting to produce new knowledge [32] (p. 14). In its' vision for 2030, the European Union ties knowledge-based economy with sustainability development goals (SDGs), among which we draw attention to SDG 8, "decent work and economic growth", and SDG 9, "industry, innovation and infrastructure" [33]. Both goals are linked to the availability of a strong, renewable human capital reserve with a considerable share of engineers, among other professions.

Therefore, the motivations of young people regarding study, work and (re)location, their values and beliefs, and their plans to invest their skills and energy in a particular socio-economic setting instead of another are of high interest. Considering this, the lack of studies concerning (future) engineers is surprising.

In the context of increased pressure on Romanian universities to keep track of the employment rate and career paths of their graduates, it becomes critically important to build a mechanism to forecast the presence of highly skilled workers in the domestic and foreign human capital reserves. This paper aims to address the migration intentions among Romanian students in engineering; a niche topic in scientific literature. Although there is a mismatch between intentions and actual preparation and action [11], an analysis of the students' mindset can prove useful to understand the future interactions between new graduates and the labor market, to develop regional and national policies regarding human capital, and to root development plans towards sustainable economic growth in databases reflecting the values, projections, and motivational triggers specific for the post-millennial youth in Romania [34].

The present paper polls Romanian engineering students regarding their migration intentions, motivations, destinations, and duration. It presents the results of a quantitative study, based on self-administered questionnaires filled in by students of the five major Romanian technical universities, covering the national level of the STEM student population. These universities educate over 80,000 students (Bachelor-Master-Doctoral levels) and are the main providers of engineering graduates in Romania [35]. The aims of the study are:

1. Diagnose Romanian technical university students regarding their migration intentions, motivations, destinations, and duration (temporary vs. permanent).

2. Predict the magnitude of migration in the polled population.

Such a two-step approach goes beyond the mere gauging of predispositions and identifying drivers for migration, adding a dimension that can be used to understand the behavior and career plans for this generation of students [6].

This research draws lessons from the existing literature and looks into the specific case of engineering students in Romania, a topic practically uncovered by studies in the recent literature, apart from its general mentioning in policy documents or surveys concerning the status of higher education in 21st century Romania [31,36]. We also follow a new trend in scientific literature, focusing on student groups rather than on the general youth population [4] (p. 2). 


\section{Materials and Methods}

The migration intentions of Romanian engineering students are not part of a significant body of literature, therefore the research started by constructing a quantitative questionnaire and building a significant database, relying on the five major technical universities of Romania, i.e., Politehnica University of Bucharest (UPB), Technical University of Civil Engineering of Bucharest (UTCB), Technical University of Cluj-Napoca (UTCN), Gheorghe Asachi Technical University of Iasi (TUIASI), and Politehnica University Timisoara (UPT). The acronyms for these universities, placed in parentheses after each official name, correspond to the official variants and are further used in the tables and figures.

The research was conducted in the period November 2019-February 2020, with the support of the academic leadership of these universities, which, after being informed of the purpose of the study, granted access to their students. A team of three researchers visited each university on site. With the collaboration of the student associations and the departments of pedagogy and teacher training, the researchers distributed to the students, at the beginning of lectures, seminars, or lab classes, the link to the online questionnaire and explained the details for filling in the responses. The link to the questionnaire (posted on Isondaje.ro, a free online Romanian survey platform) was also distributed through the online learning platforms of the five universities, but the response rate for this medium proved to be low. The presence of the research team on site ensured a better quality of responses and a higher response rate. To guarantee the anonymity of the respondents, no personal identification data were collected (such as names or contact information). No incentives were used to elicit responses, and students could opt out of filling in the questionnaire. The direct benefit of participation for students was the opportunity to express an opinion about their expectations and vision on post-graduate life.

The questionnaire constructed for this research investigated engineering students' perceptions of the migration phenomenon among peers, as well as their self-assessment of the topic with respect to motivations, destinations, and personal factors influencing the decision concerning their post-graduation strategies. Consistent with other studies on migration drivers, we included in the questionnaire factors pertaining to personal motivations (individual perceptions, desires), relational motivations (family ties), and contextual conditions (technological, educational, health, political systems) [37].

The self-administered questionnaire used for the study contained nine migration-related questions and six factual questions. One thousand seven hundred eighty-two valid questionnaires were obtained from the polled universities, spread as presented in Table 2, below:

Table 2. Distribution of respondents by university.

\begin{tabular}{lcccc}
\hline & Frequency & Percent & $\begin{array}{c}\text { Valid } \\
\text { Percent }\end{array}$ & $\begin{array}{c}\text { Cumulative } \\
\text { Percent }\end{array}$ \\
\hline $\begin{array}{l}\text { Politehnica University of Bucharest (UPB) } \\
\text { Technical University of Civil Engineering }\end{array}$ & 369 & 20.7 & 20.7 & 20.7 \\
$\begin{array}{l}\text { of Bucharest (UTCB) } \\
\text { Technical University of Cluj-Napoca }\end{array}$ & 364 & 20.4 & 20.4 & 41.1 \\
(UTCN) & 337 & 18.9 & 18.9 & 60.0 \\
$\begin{array}{l}\text { Gheorghe Asachi Technical University of } \\
\text { Iasi (TUIASI) }\end{array}$ & 354 & 19.9 & 19.9 & 79.9 \\
$\begin{array}{l}\text { Politehnica University Timisoara (UPT) } \\
\text { Total }\end{array}$ & 359 & 20.1 & 20.1 & 100.0 \\
\hline
\end{tabular}

The error rate is $\pm 3 \%$. The analysis was performed in the Statistical Package for the Social Sciences (SPSS) program, version 20.0. The goodness-to-fit Hosmer-Lemeshow test (HL test) [38] was used for the logistic regression analysis to assess the fitness of the model predicting the migration behavior.

The objectives set forth by the research group are:

- Research objective $1\left(\mathrm{RO}_{1}\right)$ : To identify the motivations behind the intention of Romanian engineering students to migrate, as seen by the polled students. 
- Research objective $2\left(\mathrm{RO}_{2}\right)$ : To measure the migration intentions of students in Romanian technical universities.

- Research objective $3\left(\mathrm{RO}_{3}\right)$ : To analyze the motivations for Romanian engineering students migration after graduation and to determine the length of the intended stay in the destination country (temporary vs. permanent migration).

- Research objective $4\left(\mathrm{RO}_{4}\right)$ : To identify the preferred destination countries for migration.

- Research objective $5\left(\mathrm{RO}_{5}\right)$ : To construct a predictive model concerning migration of the Romanian engineering students polled in the research.

Based on the findings of the consulted literature on the migration of high skilled youth [2830,37] and on the comments published in popular media, we have formulated the following research hypotheses:

Hypothesis 1 (H1). Economic factors (wages) are the main motive for migration for Romanian engineering students, in comparison to other motives (social, family, cultural). $\left(\mathrm{RO}_{1}\right)$

Hypothesis 2 (H2). On the level of intentions, Romanian engineering students prefer temporary migration over permanent migration. $\left(\mathrm{RO}_{2}\right)$

Hypothesis 3 (H3). The preferred countries of destination for migration belong to the European Union group (intra-EU migration), in comparison to other possible destinations (USA, UK, other countries in the world). $\left(\mathrm{RO}_{2}, \mathrm{RO}_{4}\right)$

Hypothesis 4 (H4). The intensity of the migration intentions among Romanian engineering students is similar to the one presented by OECD studies for the age group "young people", i.e., $50 \%$ of the student population. $\left(\mathrm{RO}_{2}\right)$

\section{Results}

This section presents the results in correlation with the research objectives, as shown after processing the responses, both for the entire sample and university-by-university, thus allowing us to understand such differences as regional preferences or center-periphery dynamics. Moreover, an in-depth analysis was undertaken in order to consider all significant variables that influence students' perceptions and decisions.

We started with an evaluation of the students' perception concerning the status of their chosen profession. According to $75.8 \%$ of the sample, there is a shortage of engineers on the labor market. However, the response does not necessarily fuel optimism concerning a strong rooting in the Romanian socio-economic context. The survey contained questions looking into the students' assessment of their situation, intentions, and aspirations.

\subsection{Motivations behind the Intention of Romanian Engineering Students to Migrate, as Seen by the Polled Students}

Financial reasons represent the main reason, identified by more than half of the respondents in our sample (63.5\%), for Romanian engineers to leave the country (Figure 1). These response options are followed by better work conditions abroad $(9.4 \%)$, better living conditions $(5.2 \%)$, lack of job opportunities (4.6\%), and professional development opportunities (4.3\%).

For the response variant low wages in Romania/lack of money, the highest value recorded was for UTCB $(68.4 \%)$, and the lowest was for UTCN $(57 \%)$, these being the cases with the highest deviation from the average value recorded by this category (63.5\%). For the other response variants, the differences from the average values obtained were not significant.

Based on these results, we can say the first hypothesis (H1) is validated; i.e., the economic factor (wages) is the main reason for emigration, compared to other reasons (social, family, cultural). 


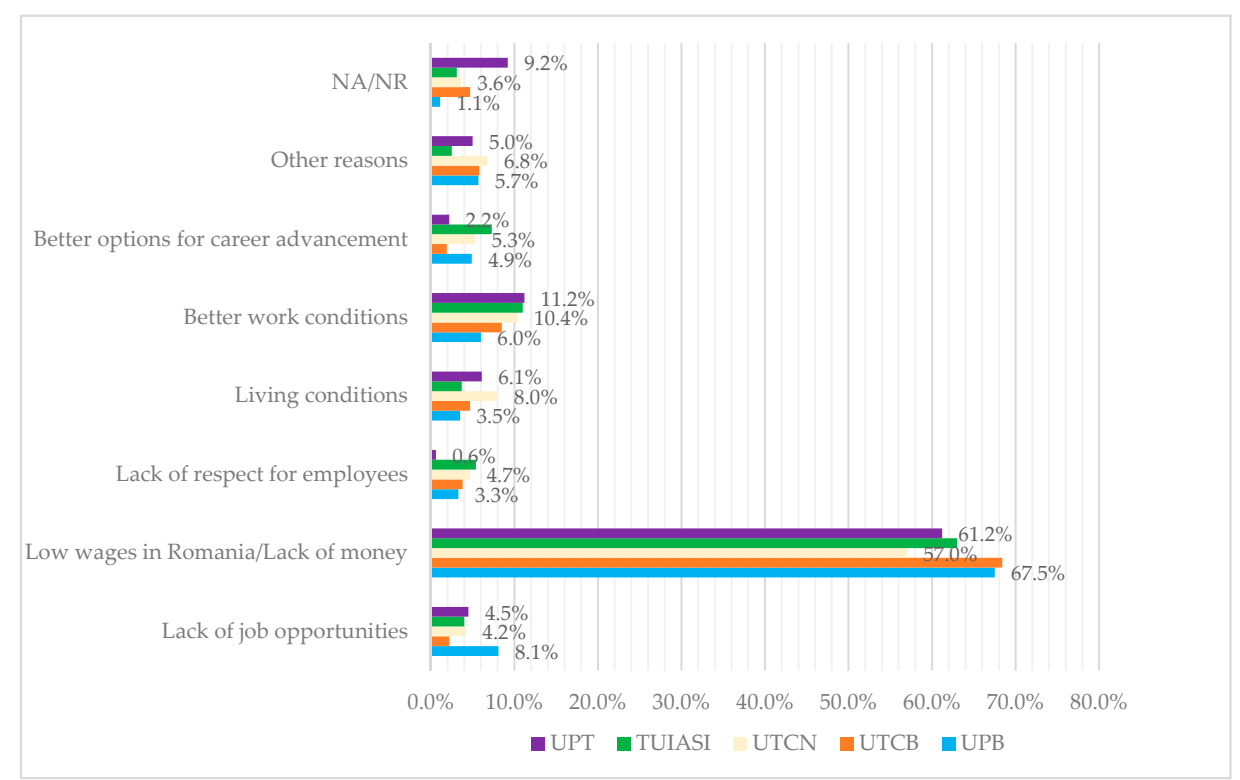

Figure 1. Migration reasons for recent graduates, given by respondents.

Because we established as a research hypothesis that the economic factor (wages) is the main reason for emigration compared to other reasons (social, family, cultural) (H1), the questionnaire included a question regarding the perception of the respondents' own financial situation, gauged on a 5-point Likert scale. Figure 2 shows that, overall, the most prominent response to this question is the average area with the good variant, chosen by $43 \%$ of respondents. The highest response for this variant is in the sample from the Technical University of Cluj Napoca (UTCN) (51.2\%). The variant neither good nor bad is chosen by $39.6 \%$ of respondents. The response very good ranks third ( $8 \%$ of the sample). The penultimate place is occupied by the poor variant $(6.4 \%)$. Finally, $3 \%$ of the respondents selected the option very poor. In other words, although very few say that they have a poor or very poor financial situation (cumulated, the two options have 9.4\%, Figure 2), the response, financial reasons $(63.5 \%)$, indicates that this is the main reason for migration identified by our students. For a future highly skilled worker position, a college graduate expects not only minimum conditions for living, but also conditions of material and professional self-realization, as seen in the presentation of the following results (in connection with $\mathrm{RO}_{5}$ ).

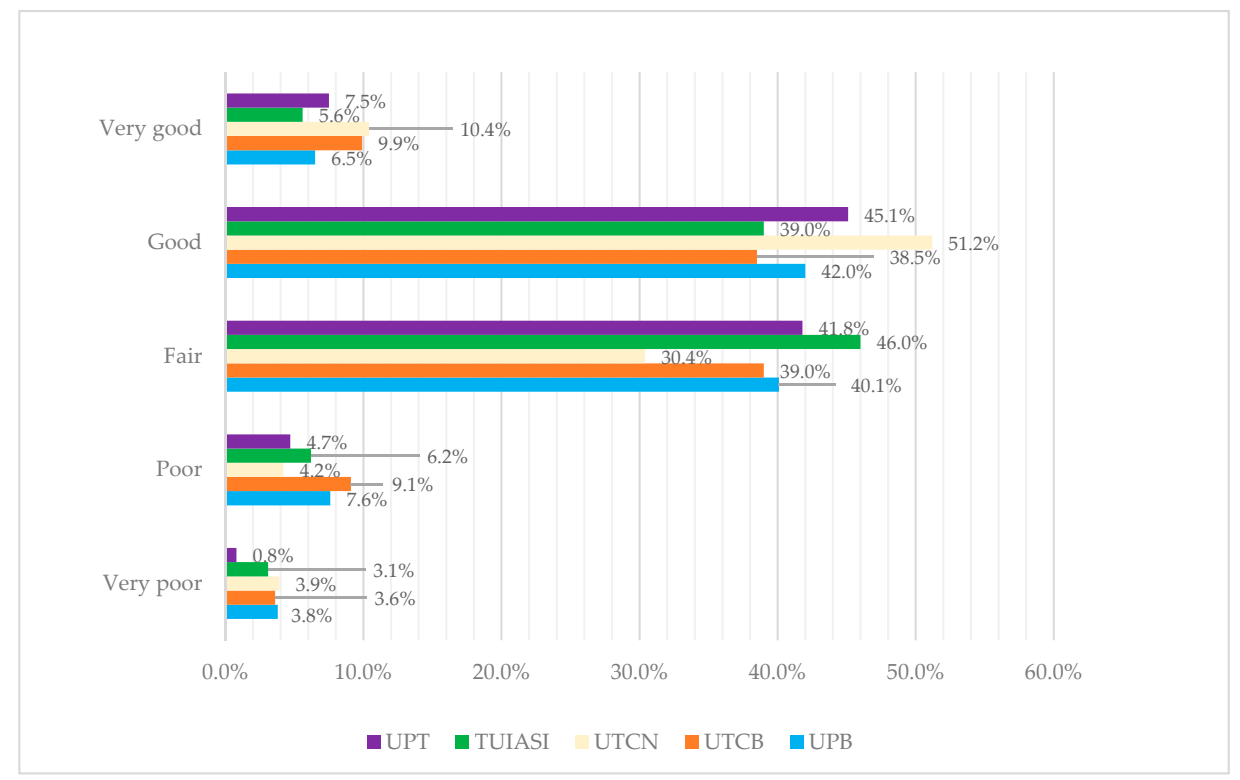

Figure 2. Appreciation of the respondents' own financial situation. 
This result resonates with the evaluation of migration drivers for most new European Union countries, which are capable of ensuring relatively low wage levels for comparatively similar work in the so-called "old EU countries" $[1,3,8,9,28]$. The desire for financial security, although recognized as not being the singular factor considered for migration aspiration, plays a very prominent role.

\subsection{The Migration Intentions of Students in Romanian Technical Universities}

Another issue of interest in this study was to measure how the students perceived their peers' intention to migrate after completing their studies and to work abroad. Figure 3 reveals that the highest frequency of answers in the whole sample is occupied by the category 1-5 colleagues $(42.5 \%)$. Within this category, the lowest rate was encountered in the sample from TUIASI (35.6\%) and the highest at UTCN $(47.6 \%)$. The following category, in descending order of percentages obtained in the overall sample, is the category $6-10$ colleagues, a response that weights $27.2 \%$. The lowest percentages for this category were obtained from respondents from UTCN $(22.3 \%)$, and the highest value recorded were from UPB (31.4\%). The choice 10-20 colleagues was preferred by $12.3 \%$ of the respondents, also with variations among universities. According to the responses, the lowest response rate is encountered at UTCN $(9.2 \%)$, while TUIASI has the highest preference $(17.5 \%)$. The intention to migrate estimated for groups of 20 colleagues or more was recorded in $8.8 \%$ of cases, with most of the respondents registered in this category at TUIASI $(11.9 \%)$, and the lowest rate at UPB $(6.8 \%)$. Of course, the choice for the category of those who do not wish to emigrate after completing their studies was also available. The category was chosen by $9.3 \%$ of the total sample, the lowest percentage values being found at TUIASI (7.3\%) and the highest at UTCN (12.2\%).



Figure 3. Intentions of students' colleagues to migrate after graduation, to work abroad.

From the evaluation of the mindset of their generation, students were asked to assess their own intentions. Across the entire sample, $23.8 \%$ of the respondents declared that, after completing their studies, they intended to leave Romania and work abroad (Figure 4). By university, the highest response choice in this category comes from TUIASI $(30.8 \%)$, followed in descending order by students from UTCB (27.7\%), UPB (24.9\%), and UTCN (19.9\%). The lowest response choice for this category was recorded by students from UPT, with $15.6 \%$. Forty-five percent of the respondents declared that they had not made up their minds. The remaining difference of $31.1 \%$ is represented by students who declared that they are determined to remain in the country after graduation and to work in Romania. 


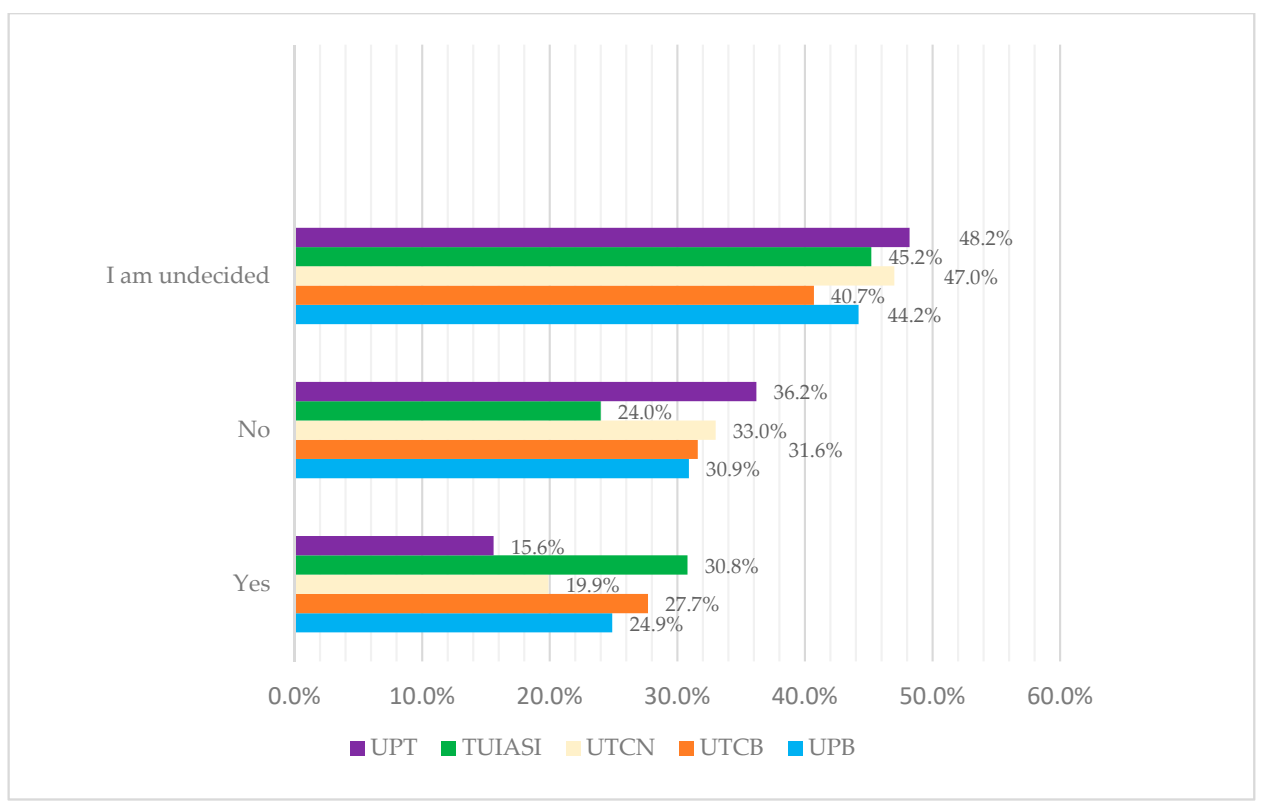

Figure 4. Intentions to migrate after graduation.

To refine the responses, we asked the students who declared their intentions to migrate to rate their intention in relation to the intensity of their desire. The table below (Table 3) indicates that the attitude towards the intention to emigrate among the student population included in the study is rather reserved. The sum of the scores obtained in the response variants very little extent and little extent totals $44.6 \%$, while the sum of the response variants very large extent and large extent totals $22.5 \%$. In other words, the share of the undecided is almost twice as much as that of those determined to migrate. Almost a third of the respondents declared that they were undecided on the above-mentioned issue. At the level of the universities from which the subjects interviewed come, maintaining the same way of cumulating the answers, we find that the most determined to emigrate are students from TUIASI $(27.7 \%)$ followed by those from UPB $(26.3 \%)$ and UTCB $(24.5 \%)$. In the penultimate place are students from UTCN $(19.6 \%)$, the least determined to emigrate being the students from UPT $(14.2 \%)$.

Table 3. Decision to migrate among the students included in the study.

\begin{tabular}{|c|c|c|c|c|c|c|c|}
\hline & & \multicolumn{5}{|c|}{ University } & \multirow{2}{*}{ Total } \\
\hline & & UPB & UTCB & UTCN & TUIASI & UPT & \\
\hline \multirow{5}{*}{$\begin{array}{l}\text { To what extent are you } \\
\text { determined to migrate? }\end{array}$} & Very little extent & $23.8 \%$ & $23.1 \%$ & $22.3 \%$ & $15.8 \%$ & $30.6 \%$ & $23.2 \%$ \\
\hline & Little extent & $18.7 \%$ & $21.4 \%$ & $25.9 \%$ & $20.9 \%$ & $20.6 \%$ & $21.4 \%$ \\
\hline & Some extent & $31.2 \%$ & $31.0 \%$ & $32.1 \%$ & $35.6 \%$ & $34.5 \%$ & $32.9 \%$ \\
\hline & Large extent & $17.1 \%$ & $14.0 \%$ & $11.3 \%$ & $16.1 \%$ & $10.6 \%$ & $13.9 \%$ \\
\hline & Very large extent & $9.2 \%$ & $10.4 \%$ & $8.3 \%$ & $11.6 \%$ & $3.6 \%$ & $8.6 \%$ \\
\hline \multicolumn{2}{|l|}{ Total } & $100.0 \%$ & $100.0 \%$ & $100.0 \%$ & $100.0 \%$ & $100.0 \%$ & $100.0 \%$ \\
\hline
\end{tabular}

3.3. The Motivations for Romanian Engineering Students' Migration after Graduation and the Length of the Intended Stay in the Destination Country (Temporary vs. Permanent Migration)

The duration envisaged for living and working abroad is also an important factor. The literature shows that there is a large variety of periods envisaged for temporary migration, the decision for temporary vs. permanent migration being influenced by a large range of factors $[4,20,26,30]$. Therefore, the survey included a question concerning the intended period of stay abroad for work reasons. The highest recorded score was for the range 1-3 years (22.3\%), followed by responses favoring permanent migration (18.9\%) and by those indicating a duration of stay of more than 5 years $(14.6 \%)$. As can be seen in Figure 5, the highest score of respondents determined not to leave the country 
is registered among UPT students (23.1\%), which confirms the answers to the previous question. Comparing the results among universities, the largest group of those who intend to leave the country are, for less than one year, students from UTCN $(15.8 \%)$, for an interval of 1-3 years, those from UPB $(22.8 \%)$, for $4-5$ years, students from TUIASI $(16.7 \%)$, and for more than 5 years, students from UPB $(17.3 \%)$ and those from UTCN $(21.1 \%)$.

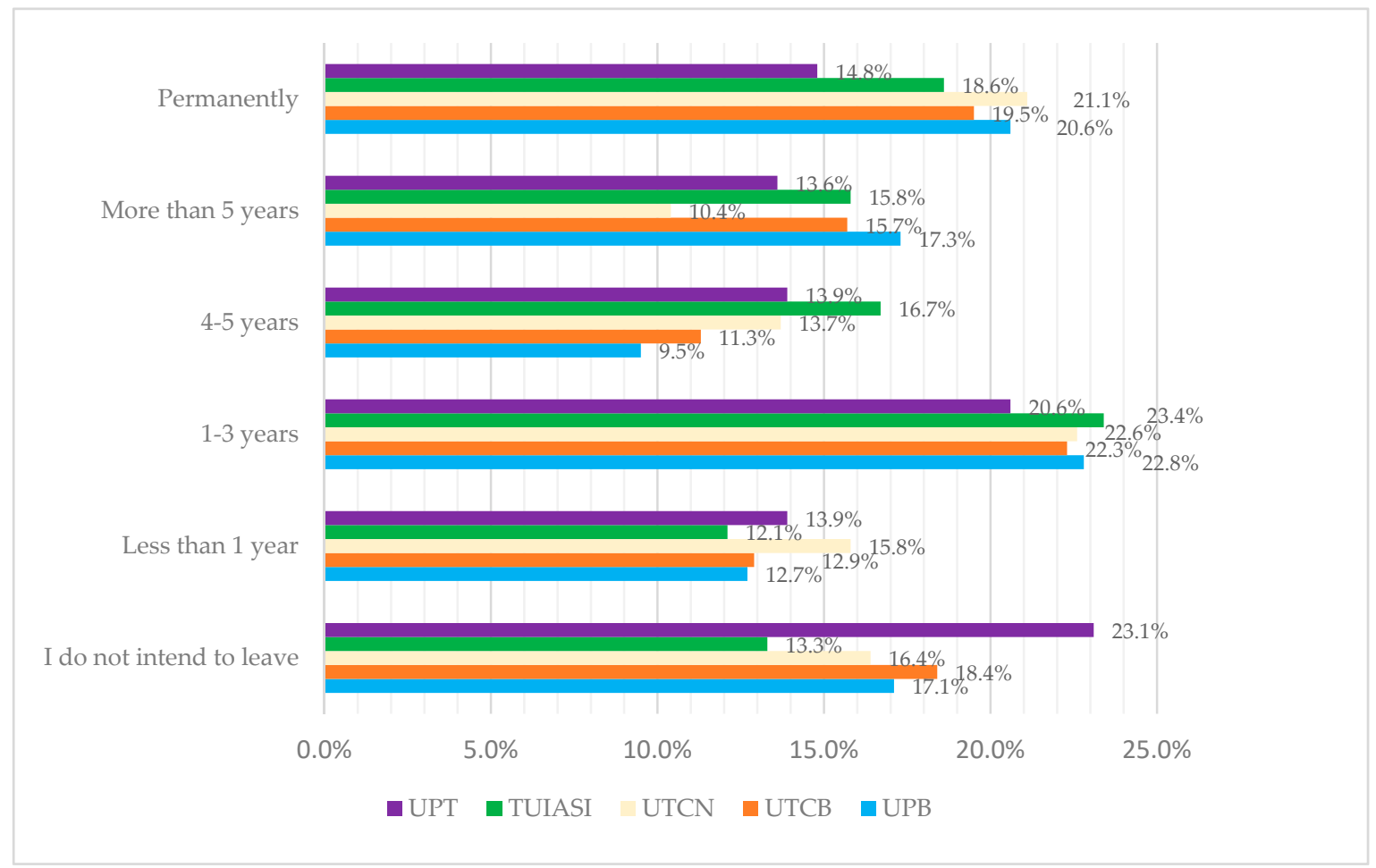

Figure 5. Duration of stay abroad.

After calculating the responses obtained for the durations of stay for relatively short periods of time (less than 1 year (13.5\%), 1-3 years (22.3\%), 4-5 years (13\%)), it can be seen that $48.8 \%$ of the sample would leave the country on a temporary basis and $18.9 \%$ intend to migrate permanently. This comparison verifies our hypothesis H2; i.e., that Romanian engineering students prefer temporary migration over permanent migration. Also, $\mathrm{H} 4$ is verified, namely the intensity of the migration intentions among Romanian engineering students is similar to the one presented by OECD studies for the age group "young people", i.e., $50 \%$ of the student population.

To examine the heterogeneity in the role of different factors influencing the decision to migrate, we introduced in the questionnaire the option to indicate the reasons for migration, ranging from personal motives (desire to gain experience, career advancement, career development, career opportunities, finding a job according to acquired skills/qualifications) up to family issues (family reunification, following a spouse/parents, etc.), educational, social, and political aspects (quality of the educational, medical, political systems, the country's prospects of economic growth, access to technology/equipment and/or technological infrastructures, corruption), and acquisition of new experiences and adventures [4,39]. Based on the statistical averages of the responses, we obtained the results summed up in the chart below (Figure 6). The following reasons rank in first places: wages/income (4.51), career opportunities (4.36), desire to gain experience/professional career (development) (4.20), and equipment and/or technology infrastructure (4.20). The three reasons ranking at the bottom of preferences are the quality of the education system (3.60), the prospects for the economic growth of the destination country (3.44), and family reasons (reunion with family, to follow a spouse/parents, etc.) (2.72). 


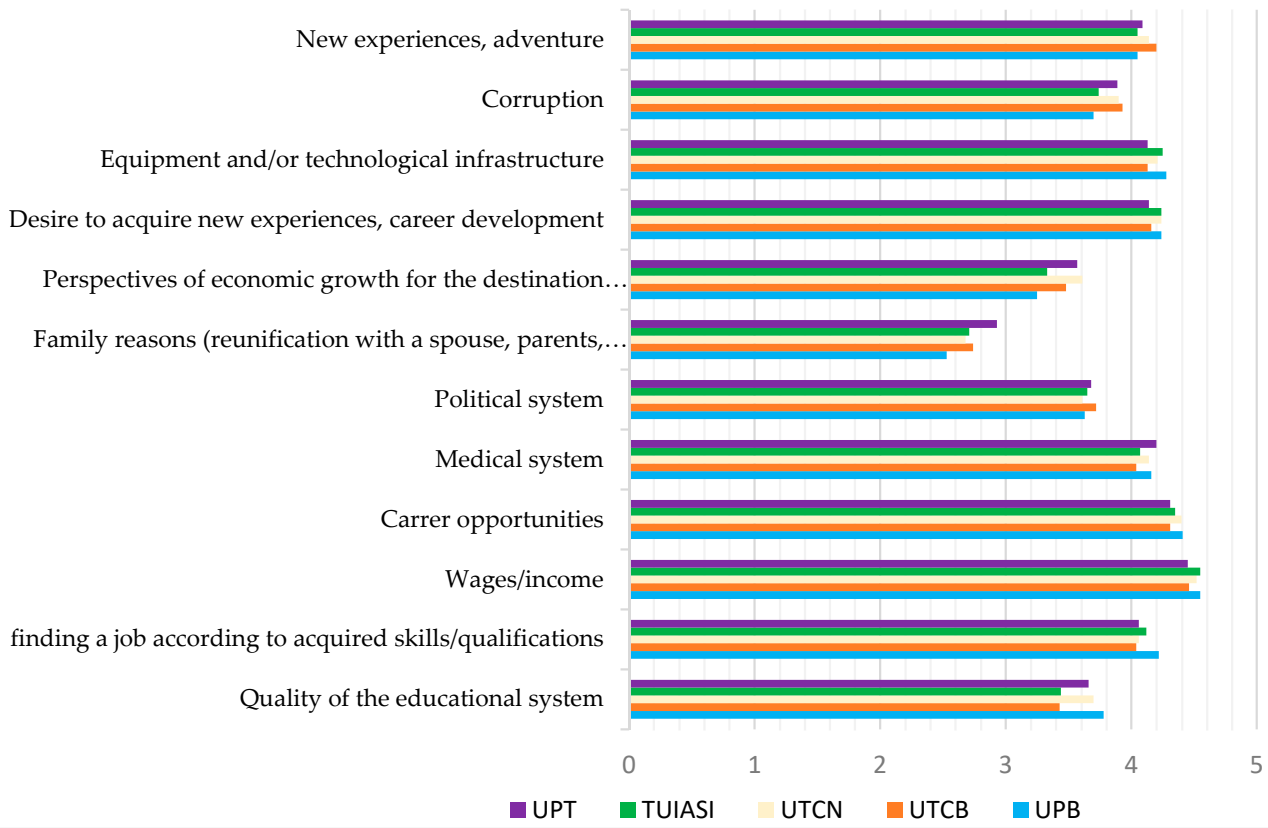

Figure 6. Reasons for migration among engineering students (values of statistical averages).

For each of the 12 reasons, the highest value of the average recorded was for:

1. Wages/income; 4.55 for UPB and TUIASI (the average for the whole sample was 4.51);

2. Career opportunities; 4.41 for UPB (the average for the whole sample was 4.36);

3. Desire to gain work experience/professional career (advancement); 4.24 in the case of UPB, UTCN, and TUIASI (the average for the whole sample was 4.20);

4. Equipment and/or technological infrastructure; 4.28 in the case of UPB (the average for the whole sample was 4.20);

5. Medical system; 4.20 in the case of UPT (the average for the whole sample was 4.12);

6. Acquiring new experiences, adventure; 4.20 in the case of UTCB (the average for the whole sample was 4.11);

7. Finding a job according to the skills/qualification acquired; 4.22 in the case of UPB (the average for the whole sample was 4.10);

8. Corruption; 3.93 in the case of UTCB (the average for the whole sample was 3.83);

9. Political environment; 3.72 in the case of UTCB (the average for the whole sample was 3.66);

10. Quality of the education system; 3.78 in the case of UPB (the average for the whole sample was 3.60);

11. Economic growth prospects of the country of destination; 3.61 in the case of UTCN (the average for the whole sample was 3.44);

12. Family reasons (meeting with family, to follow spouse/parents, etc.); 2.93 in the case of UPT (the average for the whole sample was 2.72).

Both Figures 2 and 6 indicate that the main reasons for emigration are related to wages and income (total sample average, 4.51). These results resonate with findings in other studies on migration intentions from new EU states [4,8,37,39]. Furthermore, studies looking into similar issues comment that family reasons (identified in our research with a total sample average of 2.72) rank low for young adults [26]. 


\subsection{The Preferred Destination Countries for Migration}

Migration studies gauge, not only intentions, but also directions of migration flows. Therefore, the survey included a question concerning the preferred destination countries for the polled engineering students. Students could express several choices. In the inventory of countries nominated by the respondents as a first option, those with the highest likelihood for migration are (Figure 7) Germany $(20.4 \%)$, the USA $(13.8 \%)$, and the United Kingdom (12.1\%). At the other end of the spectrum, the last three options are Ireland (0.7\%), Finland (0.5\%), and China (0.5\%).

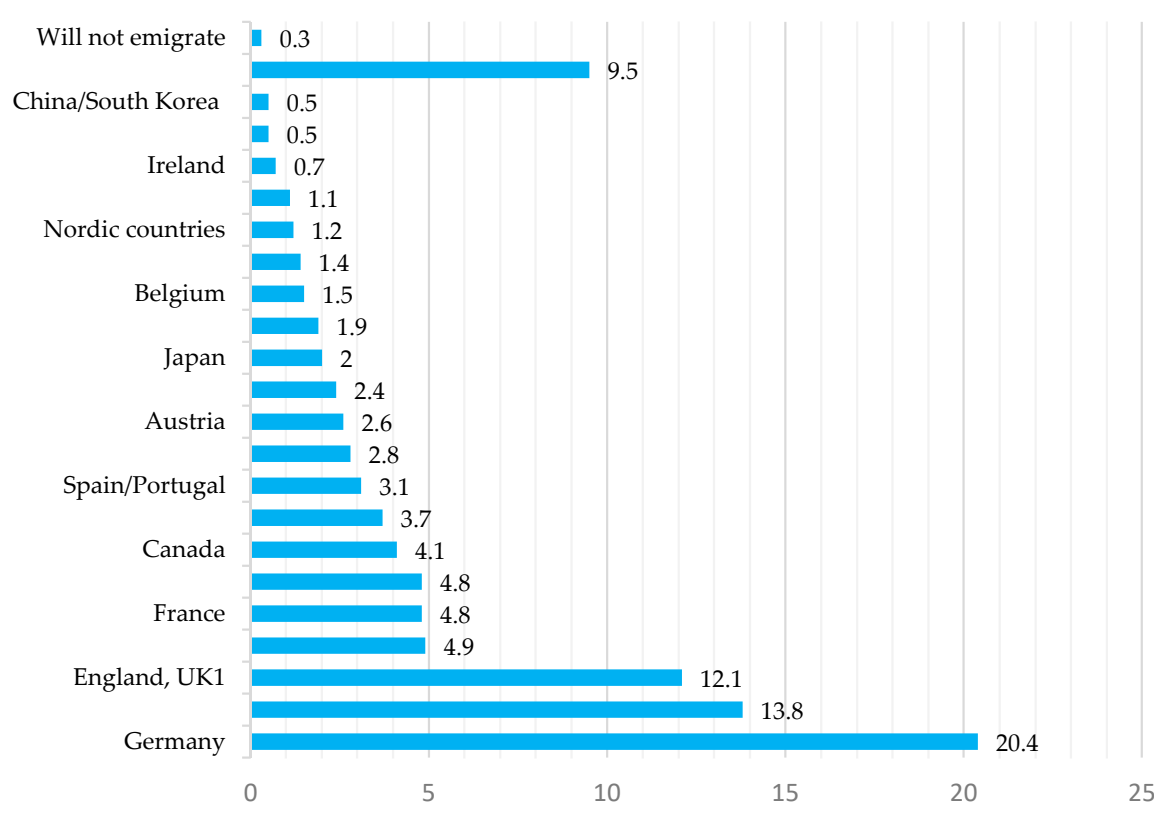

Figure 7. Countries most preferred to migrate to by the students in the sample.

The intermediary groups also deserve attention. Thus:

- Intermediate group I consists of the following countries: Netherlands (4.9\%), France (4.8\%), Switzerland (4.8\%), and Canada (4.1\%);

- Intermediate group II consists of the following countries: Norway (3.7\%) and Spain/Portugal (3.1\%);

- Intermediate group III consists of the following countries: Sweden (2.8\%), Austria (2.6\%), Denmark $(2.4 \%)$, Japan ( $2 \%)$, Italy (1.9\%), Belgium (1.5\%), Australia/New Zealand (1.4\%), Nordic countries $(1.2 \%)$, and Dubai, the United Arab Emirates, and Saudi Arabia (1.1\%).

The figure highlights the fact that there are students who are undecided or do not know what they are going to do after graduation (NA/NR, 9.5\%) or students who report that they have no intentions to move abroad $(0.3 \%)$. In recent history, Germany proved to be a magnet for Romanians, being considered as a sort of economic superstar within the European Union [8,22,37]. In second place, the USA seems desirable as a dream and as a country of possibilities, but is less attainable due to specific migration laws and quotas. The countries in last place are somewhat curious as choices, namely Finland $(0.5 \%)$, a country with a cold climate and a language quite difficult to learn for Romanians, or China/South Korea $(0.5 \%)$, which are very distant Asian countries that pose quite large linguistic and cultural barriers. Most probably these three countries at the bottom of the list appeared due to student mobility opportunities rather than career options, perceived as such after graduation. Another possible explanation is that China and South Korean have a significant economic presence in Romania as major Asian investors, but there is insufficient data to speculate on these results in the sample. 
A classification of preferred destinations by large association groups shows the following situation (Figure 8):

1. Western Europe (55\%) represents an intra-EU migration, Romania being part of it since 2007. We could say that, according to EU freedoms, the choice of a new living and workplace is not an emigration per se, but merely a movement within the "larger country";

2. The North American continent (USA and Canada) (17.1\%), an overseas mirage, is branded as immigration-friendly for many Europeans, with visa lotteries and campaigns targeting skilled labor;

3. The United Kingdom (12.1\%) has played an important role throughout modern history in the Balkans and has the aura of a center vs. periphery. The Brexit negotiations brought forth discussions regarding life/work opportunities in the UK and it became obvious that many Romanians chose this country as an emigration destination and applied for permanent residence. At the time of Brexit, official statistics in the UK showed that more than 400,000 Romanians permanently lived in the UK, this being the second largest non-British group (after Polish people) $[37,40]$.

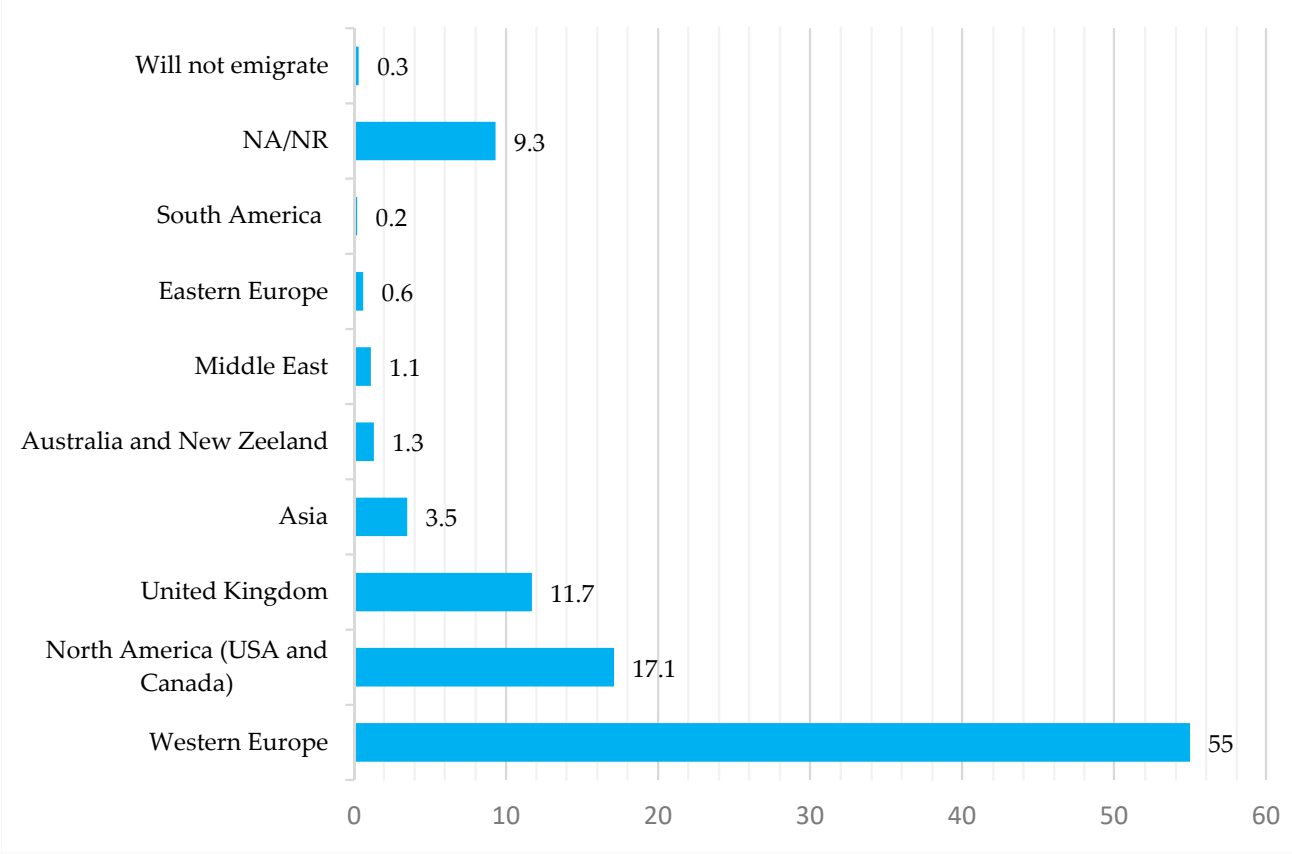

Figure 8. Groups of destination countries by region and continent.

All of the above information verifies hypothesis H3, i.e., that the preferred countries of destination for migration belong to the European Union (intra-EU migration) in comparison to other possible destinations (USA, UK, other countries in the world). This trend was identified by OECD, which evaluated that $90 \%$ of all Romanian migrants prefer European countries as destinations over other places in the developed world [8].

To refine interpretations of the destinations and intentions of emigration, we asked our respondents if they had any members of the family living and working abroad. Out of the 1783 respondents, $64.3 \%$ answered this question in the affirmative (Table 4 ). This indicates the large impact that emigration has on Romanian social and economic life. In turn, 35.7\% answered this question in the negative, a response resonating with findings in other studies discussing the migration flows in 21st century Europe [10,14]. 
Table 4. Family members abroad.

\begin{tabular}{|c|c|c|c|c|c|}
\hline \multicolumn{6}{|c|}{ Do You Have at Least One Family Member who already Emigrated? } \\
\hline & & Frequency & Percent & Valid Percent & Cumulative Percent \\
\hline \multirow{3}{*}{ Valid } & Yes & 1146 & 64.3 & 64.3 & 64.3 \\
\hline & No & 636 & 35.7 & 35.7 & 100.0 \\
\hline & Total & 1782 & 99.9 & 100.0 & \\
\hline Missing & System & 1 & 0.1 & & \\
\hline Total & & 1783 & 100.0 & & \\
\hline
\end{tabular}

The correlation between the question Do you have at least one family member who has already emigrated? and the question Do you intend to work abroad after graduation? shows a weak correlation $\mathrm{r}=0.115$ $(p<0.01)$ (Table 5). This means that family reunification is not the main inner driver for migration, but other aspects (mainly financial) are, as referred to in Research Objective 1 and set out in Figure 1.

Table 5. Correlation between the intention to migrate and the existence of a family member who has already emigrated.

\begin{tabular}{cccc}
\hline & \multicolumn{2}{c}{ Correlations } \\
\hline & $\begin{array}{c}\text { Do You Intend to Work } \\
\text { Abroad after Graduation? }\end{array}$ & $\begin{array}{c}\text { Do You Have at Least one } \\
\text { Family Member who has } \\
\text { already Emigrated? }\end{array}$ \\
\hline \multirow{2}{*}{$\begin{array}{c}\text { Do you intend to work } \\
\text { abroad after graduation? }\end{array}$} & Pearson Correlation & 1 & $0.115^{* *}$ \\
\cline { 2 - 4 } & Sig. (2-tailed) & 0.000 \\
\hline \multirow{2}{*}{$\begin{array}{c}\text { Do you have at least one } \\
\text { family member who has } \\
\text { already emigrated? }\end{array}$} & Pearson Correlation & 980 & 980 \\
\cline { 2 - 4 } & Sig. (2-tailed) & $0.115^{* *}$ & 1 \\
\hline & N & 0.000 & 1782 \\
\hline
\end{tabular}

3.5. Constructing a Predictive Model Concerning the Migration of Romanian Engineering Students Comprised in the Research

To formulate a prediction of the likelihood that our respondents will transform intentions to emigrate into action, based on the motives gauged in the questionnaire, we carried out a regression analysis. The pre-regression analysis step is the calculation of correlation coefficients. For ordinary variables we used Spearman' rank correlation coefficient.

As indicated in Table 6, the following correlation coefficients can be established between the decisiveness to migrate and the possible reasons identified to drive migration: quality of the educational system ( $\left.\mathrm{r}=0.228^{* *}, p<0.01\right)$; finding a job corresponding to the acquired skills/qualification $\left(\mathrm{r}=0.266^{* *}\right.$, $p<0.01)$; wages/income $\left(\mathrm{r}=0.160^{* *}, p<0.01\right)$; career opportunities $\left(\mathrm{r}=0.256^{* *}, p<0.01\right)$; medical system $\left(\mathrm{r}=0.144^{* *}, p<0.01\right)$; political environment $\left(\mathrm{r}=0.133^{* *}, p<0.01\right)$; family reasons $\left(\mathrm{r}=-0.052^{* *}, p<0.05\right)$; economic growth prospects of the destination country $\left(\mathrm{r}=0.173^{* *}, p<0.01\right)$; desire to gain work experience, professional career (advancement) $\left(\mathrm{r}=0.197^{* *}, p<0.01\right)$; equipment and/or technological infrastructure $\left(\mathrm{r}=0.208^{* *}, p<0.01\right)$; corruption $\left(\mathrm{r}=0.111^{* *}, p<0.01\right)$; gaining new experiences, adventure $(\mathrm{r}=0.214$ $\left.{ }^{* *}, p<0.01\right)$; existence of a family member abroad $\left(\mathrm{r}=0.123^{* *}, p<0.01\right)$; and description of the current material-financial situation $\left(\mathrm{r}=-0.094^{* *}, p<0.01\right)$. Between the intentions to emigrate and fourteen of the reasons established as drivers for migration, we recorded small but positive correlation coefficients and a threshold of significance. For the relationship between family reasons and the determination to migrate, we recorded a negative correlation coefficient, $\mathrm{r}=-0.052 * *, p<0.05$. This correlation might 
indicate that, even though family reasons do not play a major role in the decision process, they are still a factor to consider. It may hinder migration if home family ties are strong or it may, on the other hand, prove to stimulate migration if a family member is already living and working abroad, as indicated by the positive correlation coefficient $r=0.123^{* *}(p<0.01)$ between the existence of a family member abroad and the decisiveness to migrate. We also calculated a negative correlation coefficient $r=-0.094$ ** $(p<0.01)$ between the description of the current material-financial situation and the decisiveness to migrate. The value of this correlation coefficient is almost insignificant. It may only hint at a qualitative trend. The better the material-financial situation of the respondent, the less likely seems to be the decision to migrate.

Table 6. Correlation between the decision to migrate and the various possible driving motives (Spearman's rank correlation).

\begin{tabular}{|c|c|c|}
\hline \multicolumn{2}{|c|}{ Migration Reasons (Live and Work Abroad) } & $\begin{array}{c}\text { To What Extent Are You } \\
\text { Determined to Leave Romania? }\end{array}$ \\
\hline \multirow{3}{*}{ 1. Quality of the education system } & Correlation Coefficient & $0.228^{* *}$ \\
\hline & Sig. (2-tailed) & 0.000 \\
\hline & Number of respondents & 1782 \\
\hline \multirow{3}{*}{$\begin{array}{l}\text { 2. Finding a job corresponding to } \\
\text { the acquired skills/qualification }\end{array}$} & Correlation Coefficient & $0.266^{* *}$ \\
\hline & Sig. (2-tailed) & 0.000 \\
\hline & Number of respondents & 1782 \\
\hline \multirow{3}{*}{ 3. Wages/Income } & Pearson Correlation & $0.160^{* *}$ \\
\hline & Sig. (2-tailed) & 0.000 \\
\hline & $\mathrm{N}$ & 1782 \\
\hline \multirow{3}{*}{ 4. Career opportunities } & Correlation Coefficient & $0.256^{* *}$ \\
\hline & Sig. (2-tailed) & 0.000 \\
\hline & Number of respondents & 1782 \\
\hline \multirow{3}{*}{ 5. Medical system } & Correlation Coefficient & $0.144^{* *}$ \\
\hline & Sig. (2-tailed) & 0.000 \\
\hline & Number of respondents & 1782 \\
\hline \multirow{3}{*}{ 6. Political environment } & Correlation Coefficient & $0.133 * *$ \\
\hline & Sig. (2-tailed) & 0.000 \\
\hline & Number of respondents & 1782 \\
\hline \multirow{3}{*}{ 7. Family reasons } & Correlation Coefficient & $-0.052 *$ \\
\hline & Sig. (2-tailed) & 0.027 \\
\hline & Number of respondents & 1782 \\
\hline \multirow{3}{*}{$\begin{array}{l}\text { 8. Prospects for economic growth } \\
\text { of the destination country }\end{array}$} & Correlation Coefficient & 0.173 ** \\
\hline & Sig. (2-tailed) & 0.000 \\
\hline & Number of respondents & 1782 \\
\hline \multirow{3}{*}{$\begin{array}{l}\text { 9. Desire to gain work experience, } \\
\text { professional career (advancement) }\end{array}$} & Correlation Coefficient & $0.197^{* *}$ \\
\hline & Sig. (2-tailed) & 0.000 \\
\hline & Number of respondents & 1782 \\
\hline \multirow{3}{*}{$\begin{array}{l}\text { 10. Equipment/technological } \\
\text { infrastructure }\end{array}$} & Correlation Coefficient & $0.208^{* *}$ \\
\hline & Sig. (2-tailed) & 0.000 \\
\hline & Number of respondents & 1782 \\
\hline
\end{tabular}


Table 6. Cont.

\begin{tabular}{|c|c|c|}
\hline \multicolumn{2}{|c|}{ Migration Reasons (Live and Work Abroad) } & $\begin{array}{c}\text { To What Extent Are You } \\
\text { Determined to Leave Romania? }\end{array}$ \\
\hline \multirow{3}{*}{ 11. Corruption } & Correlation Coefficient & $0.111^{* *}$ \\
\hline & Sig. (2-tailed) & 0.000 \\
\hline & $\begin{array}{l}\text { Number of respondents } \\
\text { de }\end{array}$ & 1782 \\
\hline \multirow{3}{*}{$\begin{array}{l}\text { 12. Acquiring new experiences, } \\
\text { adventure }\end{array}$} & Correlation Coefficient & $0.214^{* *}$ \\
\hline & Sig. (2-tailed) & 0.000 \\
\hline & Number of respondents & 1782 \\
\hline \multirow{3}{*}{$\begin{array}{l}\text { 13. Do you have at least one family } \\
\text { member who has already } \\
\text { emigrated? }\end{array}$} & Correlation Coefficient & $0.123 * *$ \\
\hline & Sig. (2-tailed) & 0.000 \\
\hline & Number of respondents & 1782 \\
\hline \multirow{3}{*}{$\begin{array}{l}\text { 14. How would you describe your } \\
\text { current personal situation from a } \\
\text { material-financial point of view? }\end{array}$} & Correlation Coefficient & $-0.094^{* *}$ \\
\hline & Sig. (2-tailed) & 0.000 \\
\hline & Number of respondents & 1782 \\
\hline
\end{tabular}

${ }^{*}$ Correlation is significant at the 0.05 level (2-tailed). ${ }^{* *}$ Correlation is significant at the 0.01 level (2-tailed).

As we deal with ordinal variables, we used a multi-nominal logistic regression; a rather flexible procedure that allows for appropriate explanations in the case at hand.

In Table 7, we present the distribution of the variables with the possible predictive analysis. The dependent variable whose prediction we want to outline records the following responses: not likely (leaning towards no) (44.6\%), somewhat likely (neutral) (32.9\%), and likely (leaning towards yes) (22.5\%). Furthermore, the dependent variable, the determination to emigrate, registers a single observed value in $98.1 \%$ of the subpopulation.

Table 7. Distribution of each analyzed variable.

\begin{tabular}{|c|c|c|c|}
\hline \multicolumn{4}{|c|}{ Case Processing Summary } \\
\hline & & $\mathbf{N}$ & Marginal Percentage \\
\hline \multirow{3}{*}{ 1. Decision to migrate } & Not likely & 795 & $44.6 \%$ \\
\hline & Somewhat likely & 586 & $32.9 \%$ \\
\hline & likely & 401 & $22.5 \%$ \\
\hline \multirow{5}{*}{ 2. Quality of the educational system } & Very little extent & 121 & $6.8 \%$ \\
\hline & Little extent & 213 & $12.0 \%$ \\
\hline & Some extent & 449 & $25.2 \%$ \\
\hline & Large extent & 471 & $26.4 \%$ \\
\hline & Very large extent & 528 & $29.6 \%$ \\
\hline \multirow{5}{*}{$\begin{array}{l}\text { 3. Finding a job according to the acquired } \\
\text { skills/qualification }\end{array}$} & Very little extent & 56 & $3.1 \%$ \\
\hline & Little extent & 63 & $3.5 \%$ \\
\hline & Some extent & 303 & $17.0 \%$ \\
\hline & Large extent & 581 & $32.6 \%$ \\
\hline & Very large extent & 779 & $43.7 \%$ \\
\hline
\end{tabular}


Table 7. Cont.

\begin{tabular}{|c|c|c|c|}
\hline \multicolumn{4}{|c|}{ Case Processing Summary } \\
\hline & & $\mathbf{N}$ & Marginal Percentage \\
\hline \multirow{5}{*}{ 4. Wages/Income } & Very little extent & 35 & $2.0 \%$ \\
\hline & Little extent & 30 & $1.7 \%$ \\
\hline & Some extent & 141 & $7.9 \%$ \\
\hline & Large extent & 366 & $20.5 \%$ \\
\hline & Very large extent & 1210 & $67.9 \%$ \\
\hline \multirow{5}{*}{ 5. Career opportunities } & Very little extent & 32 & $1.8 \%$ \\
\hline & Little extent & 36 & $2.0 \%$ \\
\hline & Some extent & 212 & $11.9 \%$ \\
\hline & Large extent & 488 & $27.4 \%$ \\
\hline & Very large extent & 1014 & $56.9 \%$ \\
\hline \multirow{5}{*}{ 6. Medical system } & Very little extent & 45 & $2.5 \%$ \\
\hline & Little extent & 99 & $5.6 \%$ \\
\hline & Some extent & 321 & $18.0 \%$ \\
\hline & Large extent & 447 & $25.1 \%$ \\
\hline & Very large extent & 870 & $48.8 \%$ \\
\hline \multirow{5}{*}{ 7. Political system } & Very little extent & 150 & $8.4 \%$ \\
\hline & Little extent & 167 & $9.4 \%$ \\
\hline & Some extent & 489 & $27.4 \%$ \\
\hline & Large extent & 313 & $17.6 \%$ \\
\hline & Very large extent & 663 & $37.2 \%$ \\
\hline \multirow{5}{*}{ 8. Family reasons } & Very little extent & 531 & $29.8 \%$ \\
\hline & Little extent & 290 & $16.3 \%$ \\
\hline & Some extent & 404 & $22.7 \%$ \\
\hline & Large extent & 268 & $15.0 \%$ \\
\hline & Very large extent & 289 & $16.2 \%$ \\
\hline \multirow{5}{*}{$\begin{array}{l}\text { 9. Economic growth prospects of the } \\
\text { destination country }\end{array}$} & Very little extent & 173 & $9.7 \%$ \\
\hline & Little extent & 214 & $12.0 \%$ \\
\hline & Some extent & 500 & $28.1 \%$ \\
\hline & Large extent & 439 & $24.6 \%$ \\
\hline & Very large extent & 456 & $25.6 \%$ \\
\hline \multirow{5}{*}{$\begin{array}{l}\text { 10. Desire to accumulate work } \\
\text { experiences, professional career } \\
\text { (advancement) }\end{array}$} & Very little extent & 40 & $2.2 \%$ \\
\hline & Little extent & 56 & $3.1 \%$ \\
\hline & Some extent & 277 & $15.5 \%$ \\
\hline & Large extent & 539 & $30.2 \%$ \\
\hline & Very large extent & 870 & $48.8 \%$ \\
\hline \multirow{5}{*}{$\begin{array}{l}\text { 11. Equipment and/or technological } \\
\text { infrastructure }\end{array}$} & Very little extent & 36 & $2.0 \%$ \\
\hline & Little extent & 56 & $3.1 \%$ \\
\hline & Some extent & 305 & $17.1 \%$ \\
\hline & Large extent & 503 & $28.2 \%$ \\
\hline & Very large extent & 882 & $49.5 \%$ \\
\hline
\end{tabular}


Table 7. Cont.

\begin{tabular}{|c|c|c|c|}
\hline \multicolumn{4}{|c|}{ Case Processing Summary } \\
\hline & & $\mathbf{N}$ & Marginal Percentage \\
\hline \multirow{5}{*}{ 12. Corruption } & Very little extent & 174 & $9.8 \%$ \\
\hline & Little extent & 160 & $9.0 \%$ \\
\hline & Some extent & 311 & $17.5 \%$ \\
\hline & Large extent & 288 & $16.2 \%$ \\
\hline & Very large extent & 849 & $47.6 \%$ \\
\hline \multirow{5}{*}{ 13. New experiences (adventure) } & Very little extent & 44 & $2.5 \%$ \\
\hline & Little extent & 79 & $4.4 \%$ \\
\hline & Some extent & 343 & $19.2 \%$ \\
\hline & Large extent & 494 & $27.7 \%$ \\
\hline & Very large extent & 822 & $46.1 \%$ \\
\hline \multirow{2}{*}{$\begin{array}{l}\text { 14. Do you have at least one family } \\
\text { member who has already emigrated? }\end{array}$} & No & 636 & $35.7 \%$ \\
\hline & Yes & 1146 & $64.3 \%$ \\
\hline \multirow{5}{*}{$\begin{array}{l}\text { 15. How would you describe your current } \\
\text { personal situation from a } \\
\text { material-financial point of view? }\end{array}$} & Very poor & 54 & $3.0 \%$ \\
\hline & poor & 114 & $6.4 \%$ \\
\hline & fair & 705 & $39.6 \%$ \\
\hline & good & 767 & $43.0 \%$ \\
\hline & Very good & 142 & $8.0 \%$ \\
\hline Valid & & 1782 & $100.0 \%$ \\
\hline Missing & & 0 & \\
\hline Total & & 1782 & \\
\hline Subpopulation & & $1686^{a}$ & \\
\hline
\end{tabular}

${ }^{a}$ The dependent variable has only one value observed in 1654 (98.1\%) subpopulations.

To further refine the model, we applied a Stepwise regression that helped rank the motives for migration perceived by our respondents (Table 8).

Table 8. Order of the variables introduced in Stepwise regression.

\begin{tabular}{|c|c|c|c|c|c|c|}
\hline \multicolumn{7}{|c|}{ Step Summary } \\
\hline \multirow{2}{*}{ Model } & \multirow{2}{*}{ Action } & \multirow{2}{*}{ Effect(s) } & \multirow{2}{*}{$\begin{array}{c}\text { Model Fitting Criteria } \\
-2 \text { Log Likelihood }\end{array}$} & \multicolumn{3}{|c|}{ Effect Selection Tests } \\
\hline & & & & Chi-Square $^{a}$ & df & Sig. \\
\hline 0 & Entered & Intercept & 3653.705 & & & \\
\hline 1 & Entered & $\begin{array}{l}\text { Finding a job } \\
\text { according to the } \\
\text { acquired } \\
\text { skills/qualification }\end{array}$ & 3511.901 & 141.803 & 8 & 0.000 \\
\hline 2 & Entered & $\begin{array}{l}\text { Equipment and/or } \\
\text { technological } \\
\text { infrastructure }\end{array}$ & 3466.312 & 45.590 & 8 & 0.000 \\
\hline 3 & Entered & $\begin{array}{l}\text { Quality of the } \\
\text { educational system }\end{array}$ & 3427.946 & 38.366 & 8 & 0.000 \\
\hline 4 & Entered & $\begin{array}{l}\text { At least one family } \\
\text { member emigrated }\end{array}$ & 3405.074 & 22.872 & 2 & 0.000 \\
\hline
\end{tabular}


Table 8. Cont.

\begin{tabular}{|c|c|c|c|c|c|c|}
\hline \multicolumn{7}{|c|}{ Step Summary } \\
\hline \multirow{2}{*}{ Model } & \multirow{2}{*}{ Action } & \multirow{2}{*}{ Effect(s) } & \multirow{2}{*}{$\begin{array}{c}\text { Model Fitting Criteria } \\
-2 \text { Log Likelihood }\end{array}$} & \multicolumn{3}{|c|}{ Effect Selection Tests } \\
\hline & & & & Chi-Square $^{a}$ & df & Sig. \\
\hline 5 & Entered & $\begin{array}{l}\text { Family reasons } \\
\text { (re-unification with } \\
\text { family, to follow a } \\
\text { spouse, parents, } \\
\text { etc.) }\end{array}$ & 3375.420 & 29.653 & 8 & 0.000 \\
\hline 6 & Entered & $\begin{array}{l}\text { New experiences, } \\
\text { adventure }\end{array}$ & 3346.561 & 28.859 & 8 & 0.000 \\
\hline 7 & Entered & $\begin{array}{l}\text { Current personal } \\
\text { material-financial } \\
\text { situation }\end{array}$ & 3320.418 & 26.143 & 8 & 0.001 \\
\hline 8 & Entered & $\begin{array}{l}\text { Economic growth } \\
\text { prospects of the } \\
\text { destination country }\end{array}$ & 3303.041 & 17.378 & 8 & 0.026 \\
\hline
\end{tabular}

Stepwise Method: Forward Entry. ${ }^{a}$ The chi-square for entry is based on the likelihood ratio test.

The effects of the selection tests carried out by the SPSS program constitute an explanatory prediction model with eight variables (out of the fourteen originally introduced) that, in descending order, are the following: finding a job according to the acquired skills/qualification $\left(\chi^{2}=141.803, \mathrm{df}=8\right.$, $p<0.01)$; equipment and/or technological infrastructure $\left(\chi^{2}=45.490, \mathrm{df}=8, p<0.01\right)$; quality of the educational system $\left(\chi^{2}=38.366, \mathrm{df}=8, p<0.01\right)$; at least one family member emigrated $\left(\chi^{2}=22.872, \mathrm{df}=8\right.$, $p<0.01)$; family reasons $\left(\chi^{2}=29.653, \mathrm{df}=8, p<0.01\right)$; new experiences, adventure $\left(\chi^{2}=28.859, \mathrm{df}=8\right.$, $p<0.01)$; current personal material-financial situation $\left(\chi^{2}=26.143, \mathrm{df}=8, p<0.01\right)$; and economic growth prospects of the destination country $\left(\chi^{2}=17.378, \mathrm{df}=8, p<0.01\right)$.

Appendix B "Model Fitting" offers the value for statistics-2 Log Likelihood for the adequacy of the model (i.e., significant predictors plus the intercept). The value is significant in this case: $-2 \log$ Likelihood $=3303.041\left(\chi^{2}=350.664, \mathrm{df}=58, p<0.01\right)$. The model does not fully predict real data. The prediction, as expected, is incomplete or partial. There are additional factors that need to be considered in order to obtain a picture closer to reality. The model "Intercept Only" does not contain any of the predictive variables. The model "Final" uses the group of the best predictors to provide further detail. This allows for an improvement in the suitability of the model.

The consistency test proposed by Hosmer and Lemeshow (Goodness-of-Fit) through $p>0.05$ indicates that we can accept the null hypothesis (H0), and conclude that the data estimated in the model suit those observed in the survey (Appendix C), even if only partially.

The Cox and Snell Pseudo R-Square and the Nagelkerke Pseudo R-Square, the equivalents of R2 from the linear regression, through their very low values, show that the predictors included in the model account for only $17.9 \%$ and $20.3 \%$, respectively, of the variations in the variable decided to migrate (Appendix D).

Further, we applied the Likely Ratio Test (LRT) to understand the effect of one-by-one removal of predictor variables from the model resulting from the performed logistic regression analysis (Table 9). 
Table 9. Likelihood Ratio Tests.

\begin{tabular}{|c|c|c|c|c|}
\hline \multicolumn{5}{|c|}{ Likelihood Ratio Tests } \\
\hline \multirow[b]{2}{*}{ Effect } & \multirow{2}{*}{$\begin{array}{l}\text { Model Fitting Criteria } \\
-2 \text { Log Likelihood of } \\
\text { Reduced Model }\end{array}$} & \multicolumn{3}{|c|}{ Likelihood Ratio Tests } \\
\hline & & Chi-Square & df & Sig. \\
\hline Intercept & $3303.041^{\mathrm{a}}$ & 0.000 & 0 & \\
\hline 1. Quality of the education system & 3336.830 & 33.790 & 8 & 0.000 \\
\hline $\begin{array}{l}\text { 2. Finding a job according to the } \\
\text { acquired skills/qualifications }\end{array}$ & 3346.747 & 43.706 & 8 & 0.000 \\
\hline $\begin{array}{l}\text { 3. Family reasons (re-unification with } \\
\text { the family, following a spouse, } \\
\text { parents, etc.) }\end{array}$ & 3335.242 & 32.201 & 8 & 0.000 \\
\hline $\begin{array}{l}\text { 4. Economic growth prospects of the } \\
\text { destination country }\end{array}$ & 3320.418 & 17.378 & 8 & 0.026 \\
\hline $\begin{array}{l}\text { 5. Equipment and/or technological } \\
\text { infrastructure }\end{array}$ & 3326.955 & 23.914 & 8 & 0.002 \\
\hline 6. New experiences, adventure & 3331.276 & 28.236 & 8 & 0.000 \\
\hline $\begin{array}{l}\text { 7. At least one family member } \\
\text { emigrated }\end{array}$ & 3324.064 & 21.024 & 2 & 0.000 \\
\hline $\begin{array}{l}\text { 8. Current personal material-financial } \\
\text { situation }\end{array}$ & 3329.559 & 26.519 & 8 & 0.001 \\
\hline
\end{tabular}

Table 10 shows that eliminating one of the eight variables selected for the model adversely influences the data predicted with the rest of the data ( $p<0.05$ for any of the eight variables).

Table 10. Parameter Estimates (intercept and regression coefficients).

\begin{tabular}{|c|c|c|c|c|c|c|}
\hline & Decision to Migrate & B & $\begin{array}{c}\text { Std. } \\
\text { Error }\end{array}$ & Wald & df & Sig. \\
\hline \multirow{6}{*}{ Not likely } & Intercept & -0.104 & 0.286 & 0.133 & 1 & 0.716 \\
\hline & Quality of the educational system $=1$ & 1.240 & 0.370 & 11.229 & 1 & 0.001 \\
\hline & Quality of the educational system $=2$ & 0.793 & 0.261 & 9.224 & 1 & 0.002 \\
\hline & Quality of the educational system $=3$ & 0.508 & 0.198 & 6.594 & 1 & 0.010 \\
\hline & $\begin{array}{l}\text { Finding a job according to the acquired } \\
\text { skills/competencies }=1\end{array}$ & 2.126 & 0.678 & 9.819 & 1 & 0.002 \\
\hline & $\begin{array}{l}\text { Finding a job according to acquired } \\
\text { skills/competencies }=2\end{array}$ & 1.665 & 0.505 & 10.854 & 1 & 0.001 \\
\hline
\end{tabular}


Table 10. Cont.

\begin{tabular}{|c|c|c|c|c|c|c|}
\hline & Decision to Migrate & B & $\begin{array}{l}\text { Std. } \\
\text { Error }\end{array}$ & Wald & df & Sig. \\
\hline & $\begin{array}{l}\text { Finding a job according to acquired } \\
\text { skills/competencies }=3\end{array}$ & 0.933 & 0.229 & 16.518 & 1 & 0.000 \\
\hline & $\begin{array}{l}\text { Finding a job according to acquired } \\
\text { skills/competencies }=4\end{array}$ & 0.451 & 0.168 & 7.210 & 1 & 0.007 \\
\hline & Family reasons $=1$ & -0.701 & 0.208 & 11.338 & 1 & 0.001 \\
\hline & Family reasons $=2$ & -0.713 & 0.237 & 9.085 & 1 & 0.003 \\
\hline & $\begin{array}{l}\text { Equipment and/or technological } \\
\text { infrastructure }=2\end{array}$ & 1.171 & 0.567 & 4.259 & 1 & 0.039 \\
\hline & $\begin{array}{l}\text { Equipment and/or technological } \\
\text { infrastructure }=3\end{array}$ & 0.550 & 0.233 & 5.560 & 1 & 0.018 \\
\hline & New experiences, adventure $=2$ & 1.126 & 0.413 & 7.416 & 1 & 0.006 \\
\hline & New experiences, adventure $=3$ & 0.674 & 0.207 & 10.571 & 1 & 0.001 \\
\hline & At least one family member emigrated $=0$ & 0.596 & 0.144 & 17.228 & 1 & 0.000 \\
\hline & $\begin{array}{l}\text { Current personal material-financial situation } \\
=1\end{array}$ & -1.188 & 0.418 & 8.088 & 1 & 0.004 \\
\hline \multirow{2}{*}{ Somewhat likely } & Quality of the educational system $=3$ & 0.590 & 0.197 & 9.024 & 1 & 0.003 \\
\hline & $\begin{array}{l}\text { Equipment and/or technological } \\
\text { infrastructure }=3\end{array}$ & 0.521 & 0.234 & 4.957 & 1 & 0.026 \\
\hline
\end{tabular}

The logistical regression was carried out to determine the characteristics that differentiate the three categories of respondents according to the decision to emigrate (likely, somewhat likely, not likely). It follows that eight out of the fourteen predictor variables included in the analysis differentiate the subpopulation not inclined to emigrate (identified in the response-not likely) from those pondering the issue and responding somewhat likely. Such an assessment requires a closer look.

\subsubsection{Discussion for the Response Variant Not Likely}

The variant we consider in this section responds to the question "what makes our students in the sample stay/remain in Romania". The quality of the educational system of levels 1,2 , or 3 correspond to answers very little extent $(b=1.240, p<0.01)$, little extent $(p<0.01)$, and some extent $(p<0.01)$ on the gauging scale for this variable. In other words, if the respondent opts for the first positions in the scale, that person is satisfied by the quality of the Romanian educational system and might not be tempted to migrate.

Finding a job according to acquired skills/qualification spreads over the entire scale: $1=$ very little extent $(b=2.126, p<0.01), 2=$ little extent $(b=1.665, p<0.01), 3=$ some extent $(b=0.933, p<0.01)$, $4=$ large extent $(\mathrm{b}=0.451, p<0.01)$. Those who would not emigrate might not be motivated by the prospect of finding a good job. Because the value of $b$ decreases from 2.126 to 0.451 , we can conclude that finding a job according to skills can be a sufficiently good indicator for migration, but only in conjunction with other factors.

Family reasons occur with two variants: $1=$ very little extent $(\mathrm{b}=-0.701, p<0.01)$ and $2=$ little extent $(b=-0.713, p<0.01)$. The occurrence of $\boldsymbol{a} \boldsymbol{b}$ with a negative value for those who chose for this variable the option not to migrate shows that family issues would also be a reason for their emigration, if the situation were changed; i.e., they would decide to migrate following a family member, a friend, or a spouse engaged in migration. Family is a migration catalyst, both for the decision to move abroad, and for remaining in the origin country.

Equipment and/or technological infrastructure can be found with two steps in the gauging scale: 2 $=$ little extent $(\mathrm{b}=1.171, p<0.05)$ and $3=$ some extent $(\mathrm{b}=0.550, p<0.01)$. For those who take little 
or no interest in equipment and technology, migration does not seem to be tempting. It is possible that a decisive difference between Romania and a destination country in terms of access to superior equipment and technological infrastructure is a significant reason for migration.

New experience, adventure occur with two steps in the gauging scale: $2=$ little extent $(\mathrm{b}=1.126$, $p<0.01)$ and $3=$ some extent $(b=0.674, p<0.01)$. As the data show, those who are not keen on new experiences and adventure would not emigrate. It is difficult to predict whether changing their experience options would not change emigration trends.

At least one family member emigrated. In the regression coefficients table, only the variant $0=N o$ is present $(b=0.596, p<0.01)$. The responses indicate that the respondents with no emigration experience in the family are not likely to take the decision to move abroad.

Current personal material-financial situation is present only with the variant $1=$ poor $(b=-1.188$, $p<0.01)$. This can be interpreted as an indicator that respondents who evaluate their financial situation as poor are not necessarily interested in migrating.

\subsubsection{Discussion for the Response Variant Somewhat Likely}

Those who are undecided in terms of the desire to migrate (somewhat likely) have as predictors quality of the educational system (response level $3, \mathrm{~b}=0.590, p<0.01$ ) and equipment and/or technological infrastructure (response level, $\mathrm{b}=0.521, p<0.05$ ). These results indicate that, for this subpopulation, the two reasons, education and access to technological infrastructure, represent important drivers. Both factors influence the achievement of higher quality of work and life, parameters often seen when comparing East and West.

It is important to note that the parameter economic growth prospects of the destination country, used for building the prediction model, is not found among the predictor factors for the analyzed responses. Its influence can be identified as a direct one for the students' decisions analyzed in this research, but it is certainly a determining factor in migration that needs to be measured separately. This aspect can be traced also in Table 6, with a correlation coefficient $r=0.173^{* *}(p<0.01)$ concerning the economic growth prospects of the destination country and the decision to migrate.

For those determined not to migrate (not likely), the differentiating predictors are the following: finding a job according to the acquired skills/competencies $(b=2.126, p<0.01)$, quality of the educational $\operatorname{system}(b=1.240, p<0.01)$, equipment and/or technological infrastructure $(b=1.171 ; p<0.05)$, new experiences, adventure $(\mathrm{b}=1.126, p<0.01)$, current personal material-financial situation $(\mathrm{b}=-1.188, p<0.01)$, family reasons $(b=-0.713, p<0.01)$, and at least one family member emigrated $(b=0.596, p<0.01)$.

Table 11 shows that the predictors are strong in the cases of the respondents who decided not to migrate and who chose the not likely variant $(71.4 \%)$. The prediction is much lower for the undecided respondents who chose the somewhat likely variant (37\%) and very weak for the group responding likely to migrate $(28.7 \%)$.

Table 11. Prediction quality.

\begin{tabular}{lcccc}
\hline \multirow{2}{*}{ Observed } & \multicolumn{5}{c}{ Classification } \\
\cline { 2 - 5 } & Not Likely & Somewhat Likely & Likely & Percent Correct \\
\hline Not likely & 568 & 158 & 69 & $71.4 \%$ \\
\hline Somewhat likely & 284 & 217 & 85 & $37.0 \%$ \\
\hline Likely & 139 & 147 & 115 & $28.7 \%$ \\
\hline Overall Percentage & $55.6 \%$ & $29.3 \%$ & $15.1 \%$ & $50.5 \%$ \\
\hline
\end{tabular}




\section{Discussion and Conclusions}

The research highlights the fact that, overall, engineering students' migration intentions are high and that employment opportunities and conditions in Romania are perceived as disadvantageous, in comparison to those available in what is generally called "the old European Union member countries". Thus, the solidarity and cohesion measures undertaken by the EU in pursuing sustainable development goals and ensuring decent, well-paid jobs in all member countries can diminish the migration predisposition within the Union, but disparities are still visible and the young generation is eager to find quick-fix solutions to their aspirations.

Correlated with the research objectives, the results allow for a complex description of the students' profiles regarding their migration intentions and refine the knowledge on the skilled youth migration in the case of engineering students. Students in the sample identified as the main driver for engineers' migration the level of wages in Romania compared to those in developed Western countries; $63.6 \%$ of the respondents placing the economic factor at the top of the list. To a larger degree, almost seven times lower, the respondents demonstrated that better work conditions abroad was the second factor to be considered (9.4\%). The lowest places in the list of migration drivers were occupied by such items as better living conditions (5.2\%), lack of jobs (in Romania) (4.6\%), opportunities for career advancement $(4.3 \%)$, lack of respect for the employees $(3.5 \%)$, or other reasons, some of which might be of personal nature $(5.2 \%)$.

The question regarding perceptions concerning the migration intentions of peers' lead, in descending order, to the following responses: 1-5 colleagues ( $42.5 \%), 6-10$ colleagues $(27.2 \%), 10-20$ colleagues $(12.3 \%)$, and more than 20 colleagues $(8.8 \%)$. Results show that almost half of the sample ( $48.3 \%$ respondents) estimate that more than six colleagues intend to emigrate. The decision to migrate is firm for $22.5 \%$ of students in the sample, who chose the variants to a very large extent and to a large extent, but these numbers can be higher because there are $32.9 \%$ who cautiously chose the response to some extent.

Concerning the duration of living and working abroad, the highest response rate was registered for the time range $1-3$ years $(22.3 \%)$, followed by permanent migration $(18.9 \%)$ and by the choice over 5 years $(14.6 \%)$. In other words, one out of five of the engineering graduates from the sample favor permanent migration, and almost $15 \%$ incline towards long term migration (over 5 years). This implies that Romania potentially cannot count on more than a third of its technical highly skilled workforce. The statistical average computed for the reasons influencing the decision to migrate show that the first three places in the ranking are taken by wages/income (4.51), career opportunities (4.36), and desire to acquire new experience, professional career (advancement) (4.20). In correlation with the response on the decision to migrate, which received a third of the preferences, these responses indicate that the students do not feel that Romania gives enough career opportunities to (recent) graduates, thus favoring brain drain.

The following countries ranked first as migration destinations, in descending order: Germany $(20.4 \%)$, the USA $(13.8 \%)$, and the UK $(12.1 \%)$. By continents or regions, preferences go towards Western Europe (55\%) and the UK (12.1\%), followed by North America, represented by the USA and Canada (17.1\%).

We constructed a predictive model of emigration from Romania by applying the logistic regression using the STEPWISE method. The method lead to an explanatory prediction model consisting of eight variables, namely finding a job according to acquired skills/qualification, equipment and/or technological infrastructure, quality of the educational system, at least one family member emigrated, family reasons, new experiences, adventure, current personal material-financial situation, and economic growth prospects of the destination country. Computation indicates that the predictors included in the model account only for $17.9 \%$ in the variations for the variable decision to migrate ( $20.3 \%$ respectively).

Overall, results indicate that the quality of the educational system and equipment and/or technological infrastructure are not the main migration drivers, but, in conjunction with other factors, may influence the migration decision. The variable finding a job according to the acquired skills/qualification neither for our model, nor for the analyzed respondents represent a migration factor. It needs to be pointed out that those respondents indicating this tendency did not choose the upper scale range for finding $a$ 
job according to the acquired skills/qualification (i.e., did not select the variant $5=$ to $a$ very large extent). Also, the variable new experiences, adventure is not a migration driver for those who are not very interested in such life choices. Our respondents gathered around the levels $2=$ to a little extent and $3=$ to some extent. Respondents who consider their financial situation poor but are enrolled as students in Romania tend to envisage a career at home and seem unlikely to migrate. The respondents who do not have family members who have migrated (living and working abroad) are not tempted to migrate. Results show that family reasons can be migration drivers, to the extent that they may favor the choice to leave or to stay in an emotional relationship, but this dimension needs more in-depth analysis, not accounted for by the applied questionnaire.

The emigration rate from Romania is a matter of concern for a variety of reasons. Most major analyses on the socio-economic development and prospects for growth (carried out by the World Bank, OECD, the International Monetary Fund etc.) discuss the negative implications of the demographic decline in Romania due to low natality and high migration rates. In the Demographic Scenarios for the EU published at the end of 2019, the European Commission [41] estimates that Romania might lose up to $40 \%$ of its population due to migration by the year 2060 . The loss is particularly high in the young, active population, directly impacting the demographic sustainability of the country and its' possibility to plan for the future. We resonate with De Grip's assessment, that there is a "war for talent" going on in the world and that the brain drain is unavoidable "if wages are low or labor market prospects-as indicated by a country's R\&D intensity-are poor compared to other countries that may attract these graduates" [42]. The new European Union members are in the losing position, cohesion policy measures envisaged by the European Union having baby-step effects. On preparing its' presidency of the European Council, Romania listed, among other proposals, policy measures to reduce the intra-EU migration flows, such as labor retention actions, plans, and programs to reverse migration flows and repatriate citizens who are employed in other countries, encouraging bilateral agreements for the purpose of labor migration, etc. [43]. So far, such plans have produced little effect upon the Romanian workforce residing in other countries. Researchers have proposed, alternatively, that Romania compensate the missing skilled human capital by attracting skilled immigrants $[17,44]$, or by targeting the intended population, subjected to migration, with carefully selected measures [45].

The phenomenon of migration is a complex one, which may consider other aspects that we have not introduced in our study, mostly because there is little knowledge regarding the values and behavior of engineering students. Thus, we consider that our model, and its variables, can constitute an inflection in research and explanation for the migration of engineers as a social movement.

The study focuses on the perceptions of students only. The results are important for all the stakeholders in the educational process and for policymakers alike. The research team made the results available to the academic leaders of the surveyed universities, and it can be expected that they will initiate coordinated measures, starting with putting the debate concerning the migration of engineers from Romania on the public agenda. So far, only the drain of healthcare personnel and the shortage of medical doctors have been discussed as topics of concern.

Further research is needed to supplement the presented data and draw attention to the migration phenomenon targeting engineers. This reality is often debated in meetings between universities and industry representatives but is lacking sufficient data to be analyzed and understood as a separate phenomenon within the migration waves of highly skilled workers from Romania and from other European countries.

Author Contributions: Conceptualization, V.G., G.-M.D. and M.C.-B.; methodology, V.G. and G.-M.D.; validation, V.G., G.-M.D. and M.C.-B.; formal analysis, V.G. and G.-M.D.; investigation, V.G. and G.-M.D.; resources, V.G., G.-M.D., and M.C.-B.; writing—original draft preparation, V.G., M.G.D. and M.C.-B.; writing—review and editing, M.C.-B.; supervision, V.G., G.-M.D. and M.C.-B. All authors have read and agreed to the published version of the manuscript.

Funding: The data collection for is research was funded by The Romanian Alliance of Technical Universities (ARUT), GNaC2018-ARUT, no. 1354/01.02.2019 VALTECH-Cultural and professional values of students in Romanian technical universities. 
Conflicts of Interest: The authors declare no conflict of interest. The funders had no role in the design of the study; in the collection, analyses, or interpretation of data; in the writing of the manuscript, or in the decision to publish the results.

\section{Appendix A}

Table A1. Recent Scientific Literature on Highly Skilled Youth Migration Intentions.




Table A1. Cont.

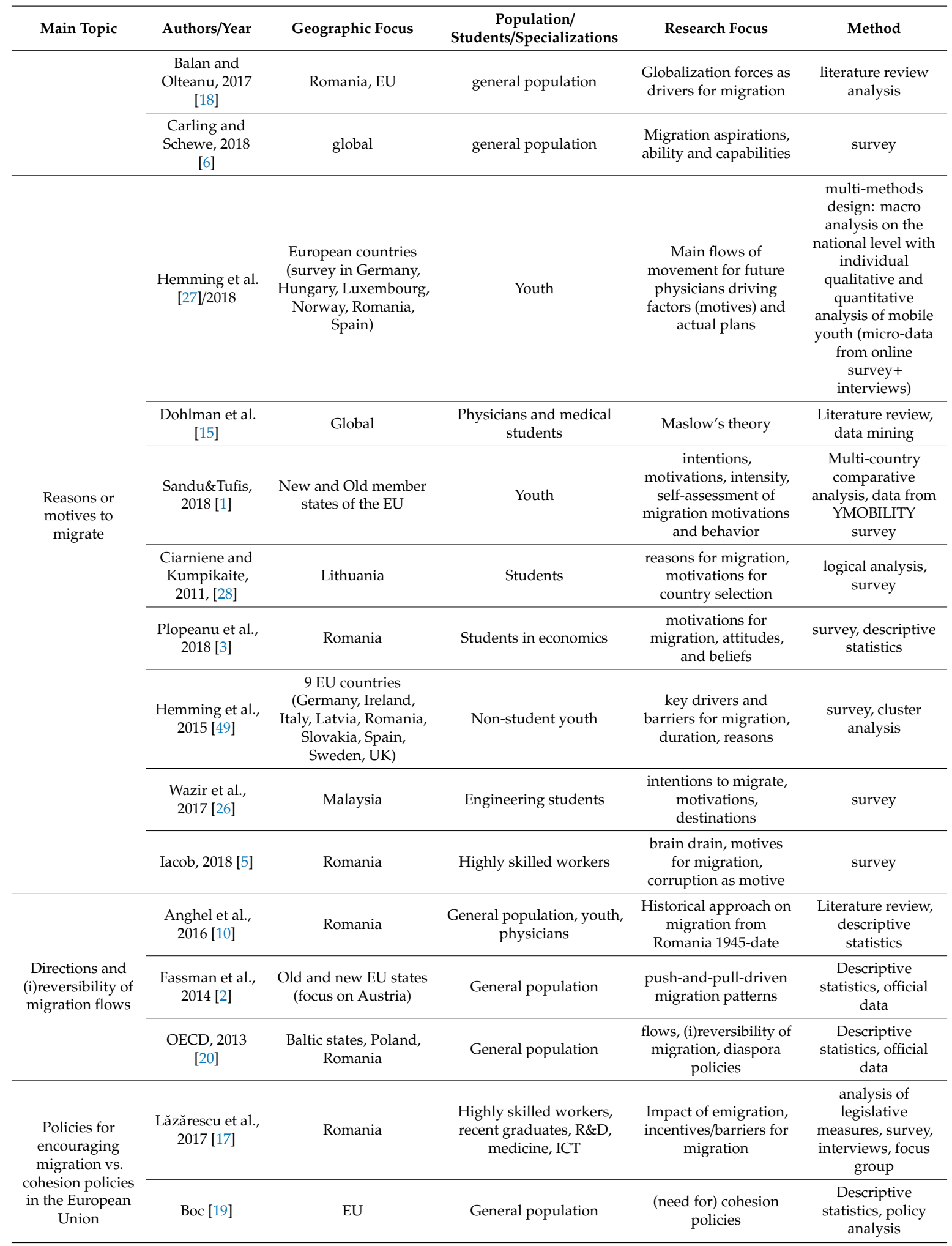


Table A1. Cont.

\begin{tabular}{|c|c|c|c|c|c|}
\hline Main Topic & Authors/Year & Geographic Focus & $\begin{array}{c}\text { Population/ } \\
\text { Students/Specializations }\end{array}$ & Research Focus & Method \\
\hline \multirow{4}{*}{$\begin{array}{c}\text { Actual } \\
\text { experiences of } \\
\text { expat highly } \\
\text { skilled workers } \\
\text { in the destination } \\
\text { country with } \\
\text { respect to a } \\
\text { variety of } \\
\text { realities }\end{array}$} & $\begin{array}{c}\text { Emilsson and } \\
\text { Mozetič, } 2019 \\
\text { [13] }\end{array}$ & $\begin{array}{l}\text { Sweden, Romania, } \\
\text { Latvia }\end{array}$ & Highly skilled youth & $\begin{array}{c}\text { Career trajectories, } \\
\text { de-skilling, migration } \\
\text { outcomes }\end{array}$ & $\begin{array}{c}\text { semi-structured } \\
\text { interviews, case } \\
\text { studies }\end{array}$ \\
\hline & $\begin{array}{l}\text { Fischer-Souan, } \\
2019 \text { [37] }\end{array}$ & SEE countries, EU & $\begin{array}{l}\text { Highly skilled and } \\
\text { lower-skilled workers }\end{array}$ & $\begin{array}{l}\text { Migration motivations, } \\
\text { perceptions on the } \\
\text { outcomes individual } \\
\text { and }\end{array}$ & $\begin{array}{l}\text { in-depth } \\
\text { interviews }\end{array}$ \\
\hline & $\begin{array}{c}\text { Demireva and } \\
\text { Quassoli, } 2019 \\
\text { [21] }\end{array}$ & EU & Migrant workers & $\begin{array}{l}\text { structural barriers } \\
\text { preventing migrants } \\
\text { from realizing their } \\
\text { human capital } \\
\text { potential }\end{array}$ & $\begin{array}{c}\text { rich qualitative } \\
\text { data in the research } \\
\text { project }\end{array}$ \\
\hline & Tanis, 2020 [22] & Germany & Migrant workers & $\begin{array}{c}\text { Location choices of } \\
\text { immigrants in } \\
\text { Germany }\end{array}$ & $\begin{array}{c}\text { descriptive } \\
\text { statistics, analysis }\end{array}$ \\
\hline \multirow{2}{*}{$\begin{array}{l}\text { Identity-building } \\
\text { and perceptions }\end{array}$} & $\begin{array}{c}\text { Van Mol, } 2019 \\
{[23]}\end{array}$ & EU & Students & European identity & Survey \\
\hline & $\begin{array}{c}\text { King et al., } 2018 \\
\text { [14] }\end{array}$ & EU & Migrants and refugees & $\begin{array}{l}\text { Historical approach on } \\
\text { migration flows }\end{array}$ & $\begin{array}{l}\text { Official statistics, } \\
\text { policy analysis }\end{array}$ \\
\hline
\end{tabular}

\section{Appendix B}

Table A2. The quality of model suitability.

\begin{tabular}{lcccc}
\hline \multicolumn{5}{c}{ Model Fitting Information } \\
\hline \multirow{2}{*}{ Model } & Model Fitting Criteria & \multicolumn{2}{c}{ Likelihood Ratio Tests } & \\
\cline { 2 - 5 } & $\mathbf{- 2}$ Log Likelihood & Chi-Square & df & Sig. \\
\hline Intercept Only & 3653.705 & & & \\
\hline Final & 3303.041 & 350.664 & 58 & 0.000 \\
\hline
\end{tabular}

\section{Appendix C}

Table A3. Table confirmation or refutation of the null hypothesis (H0).

\begin{tabular}{lccc}
\hline \multicolumn{4}{c}{ Goodness-of-Fit } \\
\hline & Chi-Square & df & Sig. \\
\hline Pearson & 3281.969 & 3312 & 0.641 \\
\hline Deviance & 3231.249 & 3312 & 0.839 \\
\hline
\end{tabular}

\section{Appendix D}

Table A4. Percentage of total variance of the dependent variable (decision to emigrate) explained by predictors.

\begin{tabular}{cc}
\hline \multicolumn{2}{c}{ Pseudo R-Square } \\
\hline Cox and Snell & 0.179 \\
\hline Nagelkerke & 0.203 \\
\hline McFadden & 0.093 \\
\hline
\end{tabular}




\section{References}

1. Sandu, D.; Tufis, P. Spheres of Life in Youth Migration Processes: A Multicountry and Multilevel Approach, Section in the Research Report of H2020 Project YMOBILITY, Youth Mobility: Maximizing Opportunities for Individuals, Labour Markets and Regions in EUROPE, 2015-2018. 2018. Available online: https://www.academia.edu/38394901/Spheres_of_Life_in_Youth_Migration_Processes_a_ Multicountry_and_Multilevel_Approach (accessed on 20 April 2020).

2. Fassmann, H.; Kohlbacher, J.; Reeger, U. The re-emergence of European East-West migration-The Austrian example. Cent. East. Eur. Migr. Rev. 2014, 3, 1-21.

3. Plopeanu, A.P.; Homocianu, D.; Mihaila, A.A.; Crisan, E.L.; Bodea, G.; Bratu, R.D.; Airinei, D. Exploring the Influence of Personal Motivations, Beliefs and Attitudes on Students' Post-Graduation Migration Intentions: Evidence from Three Major Romanian Universities. Appl. Sci. 2018, 8, 2121. [CrossRef]

4. Williams, A.M.; Jephcote, C.; Janta, H.; Li, G. The migration intentions of young adults in Europe: A comparative, multilevel analysis. Popul. Space Place 2017, e2123. [CrossRef]

5. Iacob, R. Brain Drain Phenomenon in Romania: What Comes in Line after Corruption? Rom. J. Commun. Public Relat. 2018, 20, 53-78.

6. Carling, J.; Schewel, K. Revisiting aspiration and ability in international migration. J. Ethn. Migr. Stud. 2018, 44, 945-963. [CrossRef]

7. World Bank. Migration and Brain Drain. (English). In Europe and Central Asia Economic Update; World Bank Group: Washington, DC, USA, 2019; Available online: http:/documents.worldbank.org/ curated/en/657051570692065211/World-Bank-ECA-Economic-Update-Fall-2019 (accessed on 20 April 2020).

8. OECD. Talent Abroad: A Review of Romanian Emigrants; OECD Publishing: Paris, France, 2019. [CrossRef]

9. Publications Office of the European Union. Study on the Movement of Skilled Labour: Final Report; Publications Office of the European Union: Luxembourg, 2018; ISBN 9789279934735. Available online: https://ec.europa.eu/social/main.jsp?catId=738\&langId=en\&pubId=8156\&furtherPubs=yes (accessed on 20 April 2020).

10. Anghel, R.; Botezat, A.; Coșciug, A.; Manafi, I.; Roman, M. International Migration, Return Migration, and Their Effects: A Comprehensive Review on the Romanian Case. IZA Discuss. Pap. 2016, 10445. Available online: https://ssrn.com/abstract=2895293 (accessed on 22 April 2020).

11. Migali, S.; Scipioni, M.A. Global Analysis of Intentions to Migrate; European Commission: Rome, Italy, 2018; Available online: https://ec.europa.eu/jrc/sites/jrcsh/files/technical_report_on_gallup_v7_finalpubsy.pdf (accessed on 22 April 2020).

12. Black, R.; Engbersen, G.; Okolski, M.; Pantiru, C. (Eds.) A Continent Moving West? EU Enlargement and Labour Migration from Central and Eastern Europe; Amsterdam University Press: Amsterdam, The Netherlands, 2018.

13. Emilsson, H.; Mozetič, K. Intra-EU youth mobility, human capital, and career outcomes: The case of young high-skilled Latvians and Romanians in Sweden. J. Ethn. Migr. Stud. 2019. [CrossRef]

14. King, R.; Okólski, M. Diverse, Fragile and Fragmented. The New Map of European Migration. Cent. East. Eur. Migr. Rev. 2018, 1-24. [CrossRef]

15. Dohlman, L.; DiMeglio, M.; Hajj, J.; Laudanski, K. Global Brain Drain: How Can the Maslow Theory of Motivation Improve Our Understanding of Physician Migration? Int. J. Environ. Res. Public Health 2019, 16, 1182. [CrossRef]

16. Suciu, SSM.; Popescu, C.A.; Ciumageanu, M.D.; Buzoianu, A.D. Physician migration at its roots: A study on the emigration preferences and plans among medical students in Romania. Hum. Resour. Health 2017, 15, 6. [CrossRef]

17. Lăzărescu, L.; Hambderger, A.; Șerbănică, C.; Prisăcariu, R.M. Emigrația Forței de Muncă Inalt Calificate din România. O Analiză a Domeniilor Cercetare-Dezvoltare, Medicină și Tehnologia Informației și Comunicațiilor, Raport de Cercetare; Asociaţia Română pentru Promovarea Sănătăţii: Bucuresti, Romania, 2017; Available online: http://eminet.cdcdi.ro/sites/default/files/arps/images/projects/Emigratia\%20fortei\%20de\% 20munca\%20inalt\%20calificate.pdf (accessed on 24 April 2020).

18. Bălan, M.; Olteanu, C. Brain Drain in The Globalization Era: The Case of Romania. In Annals of 'Constantin Brancusi' University of Targu-Jiu. Economy Series; University of Târgu Jiu: Targu-Jiu, Romania, 2017; Issue 3; pp. 26-35.

19. Boc, E. Brain Drain in the EU: Local and Regional Public Policies and Good Practices. Transylv. Rev. Adm. Sci. 2020, 23-39. [CrossRef] 
20. OECD. Coping with Emigration in Baltic and East European Countries; OECD Publishing: Paris, France, 2013; Available online: http://dx.doi.org/10.1787/9789264204928-en (accessed on 24 April 2020).

21. Demireva, N.; Quassoli, F. The Lived Experiences of Migration: An Introduction. Soc. Incl. 2019, 7, 1-6. [CrossRef]

22. Tanis, K. Regional distribution and location choices of immigrants in Germany. Reg. Stud. 2020, 54, 483-494. [CrossRef]

23. Van Mol, C. Intra-European student mobility and the different meanings of 'Europe'. Acta Sociol. 2019, 1-17. [CrossRef]

24. Visvizi, A.; Pachocka, M.; Lytras, M.D. Managing International Migration: Rethinking Transaction Costs, Red Tape, and Their Impact'. Int. Migr. 2019, 57, 271-279. [CrossRef]

25. National Academy of Engineering. Understanding the Educational and Career Pathways of Engineers; The National Academies Press: Washington, DC, USA, 2018. [CrossRef]

26. Wazir, F.; Jani, R.; Othman, A.; Shahabudin, M. Factors Influencing the Intention To Migrate Among Engineering Students In Malaysia: An Exploratory Study. In Proceedings of the International Business Management Conference (IBMC 2017), Kedah, Malaysia, 3-4 December 2017; pp. 220-228, ISBN 978-967-14841-4-2.

27. Hemming, K.; Schlimbach, T.; Tilmann, F.; Nienaber, B.; Roman, M.; Skrobanek, J. Structural framework conditions and individual motivations for youth-mobility: A macro-micro level approach for different European country-types. Migr. Lett. 2018, 16, 45-59, ISSN 1741-8992. Available online: https://journals. tplondon.com/index.php/ml/article/view/621 (accessed on 21 April 2020). [CrossRef]

28. Ciarniene, R.; Kumpikaite, V. International Labour Migration: Students Viewpoint. Inz. Ekon. Eng. Econ. 2011, 22, 527-533. [CrossRef]

29. Herz, A.; Chorne, L.D.; Catalan, C.D.; Altissimo, A.; Carignani, S.S. Are you mobile, too? The role played by social networks in the intention to move abroad among youth in Europe. Migr. Lett. 2018, 16, 93-104, ISSN 1741-8992. Available online: https://journals.tplondon.com/index.php/ml/article/view/622/579 (accessed on 21 April 2020). [CrossRef]

30. Van Mol, C. Migration aspirations of European youth in times of crisis. J. Youth Stud. 2016, 19, 1303-1320. [CrossRef]

31. European Commission. Education and Training Monitor 2018, Romania; European Commission: Luxembourg, 2018; Volume 2.

32. Dahlman, C.; Anderson, T. Korea and the Knowledge-Based Economy: Making the Transition; World Bank: Washington, DC, USA; OECD: Washington, DC, USA, 2000; Available online: https://openknowledge. worldbank.org/handle/10986/13845 (accessed on 3 May 2020).

33. Sustainable Development Goals-Overview. Available online: https://ec.europa.eu/eurostat/web/sdi/ overview (accessed on 3 May 2020).

34. Docquier, F.; Giovanni, P.; Ruyssen, I. The cross-country determinants of potential and actual migration. Int. Migr. Rev. 2014, 48, S37-S99. [CrossRef]

35. ARUT Students . Available online: https://www.aruteh.ro/en/education/arut-students (accessed on 21 April 2020).

36. România Educată. Available online: http://www.romaniaeducata.eu/ (accessed on 21 April 2020).

37. Fischer-Souan, M. Between 'Labour Migration' and 'New European Mobilities': Motivations for Migration of Southern and Eastern Europeans in the EU. Soc. Incl. 2019, 7, 7-17. [CrossRef]

38. Hosmer, D.W., Jr.; Lemeshow, S.; Sturdivant, R.X. Applied Logistic Regression, 3rd ed.; Wiley: New York, NY, USA, 2013.

39. Ferro, A. Brain Drain and the Academic and the Intellectual Labour Market in South East Europe. En UNESCO CEPES 2004, 23, 275-305.

40. Românii au devenit a doua minoritate în Marea Britanie. Regatul Unit, destinaţie favorită pentru cei care aleg să emigreze. Available online: https://www.mediafax.ro/life-inedit/romanii-au-devenit-a-doua-minoritatein-marea-britanie-regatul-unit-destinatie-favorita-pentru-cei-care-aleg-sa-emigreze-17232501 (accessed on 21 April 2020).

41. Lutz, W.; Amran, G.; Belanger, A.; Conte, A.; Gailey, N.; Ghio, D.; Grapsa, E.; Jensen, K.; Loichinger, E.; Marois, G.; et al. Demographic Scenarios for the EU, EUR 29739 EN; Publications Office of the European Union: Luxembourg, 2019; ISBN 978-92-76-03216-8 (online), 978-92-76-03215-1 (print), 978-92-76-07876-0 (ePub). [CrossRef] 
42. De Grip, A.; Fouarge, D.; Sauermann, J. What affects international migration of European science and engineering graduates? Econ. Innov. N. Technol. 2010, 19, 407-421. [CrossRef]

43. Romanian Ministry of Labour and Social Justice, Posibile abordări ale politicilor la nivel U.E. și național în perspectiva Președinției române a Consiliului Uniunii Europene (Consiliul U.E.). Available online: http:/www.mmuncii.ro/j33/images/Documente/MMPS/Rapoarte_si_studii_MMPS/ DPOCM/2018_-_Posibile_abordri_ale_politicilor_la_nivel_UE_Etapa_2.pdf (accessed on 21 May 2020).

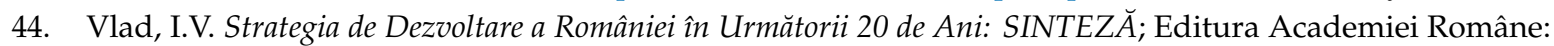
Bucharest, Romania, 2017.

45. Serban, M.; Croitoru, A. Do Return Migration Policies Matter? A typology of young Romanian returnees' attitudes towards return policies. Soc. Chang. Rev. Sciendo 2018, 16, 9-34. [CrossRef]

46. ESPON. Addressing Labour Migration Challenges in Europe. Posted on 5 June 2019; By Espon; In Policy Briefs. Available online: https://www.espon.eu/sites/default/files/attachments/ESPON\%20Policy\%20Brief\% 2C\%20Labour\%20migration\%20challenges.pdf (accessed on 5 April 2020).

47. Van Dalen, H.P.; Henkens, K. Explaining Emigration Intentions and Behaviour in the Netherlands, $2005-2010$. Popul. Stud. 2013, 67, 225-241. [CrossRef]

48. Fouarge, D.; Merve Nezihe, Ö; Seegers, P. Personality Traits, Migration Intentions, and Cultural Distance. IZA Discuss. Pap. 2019, 12444. Available online: https://ssrn.com/abstract=3415790 (accessed on 5 April 2020). [CrossRef]

49. Hemming, K.; Tillmann, F.; Reißig, B. Mapping Mobility-Pathways, Institutions and Structural Effects of Youth Mobility. European Research Project. Available online: http://move-project.eu/fileadmin/move/ downloads/MOVE_D2_4.pdf (accessed on 21 April 2020).

50. Phung, V.; Asghar, Z.; Matiti, M. Understanding how Eastern European migrants use and experience UK health services: A systematic scoping review. BMC Health Serv. Res. 2020, 20, 173. [CrossRef]

(C) 2020 by the authors. Licensee MDPI, Basel, Switzerland. This article is an open access article distributed under the terms and conditions of the Creative Commons Attribution (CC BY) license (http://creativecommons.org/licenses/by/4.0/). 